\title{
Traditional and local knowledge in land use planning: insights into the use of the Akwé: Kon Guidelines in Eanodat, Finnish Sápmi
}

\author{
Inkeri Markkula $^{1}$, Minna T. Turunen $^{1}$ and Sini Kantola ${ }^{2,3}$
}

\begin{abstract}
The 1992 Convention on Biological Diversity, Article 8(j) in particular, requires its parties to "respect, preserve and maintain knowledge, innovations and practices of Indigenous and local communities embodying traditional lifestyles." In Finland, these requirements are, to some extent, fulfilled through application of the Akwé: Kon Voluntary Guidelines, a protocol developed by the CBD for cultural, environmental, and social impact assessment to be applied in regions inhabited or used by Indigenous peoples. However, although the Akwé: Kon Guidelines have been in use for several years, studies addressing their practical application are scarce. We set out to examine the use of the Akwé: Kon Guidelines, inclusion of traditional and local knowledge (TLK), as well as the related improvements and challenges in land use planning in the Municipality of Eanodat in Finnish Sápmi. We conducted keyinformant interviews with local Sámi experts and local land use planning officials and examined recent land use and management plans for wilderness and conservation areas. Regarding the incorporation of TLK into land use planning, officials identified practical challenges, such as a mismatch between the oral narrative nature of TLK and the planning systems currently in use, and pointed to a need to make TLK more spatially explicit. The concerns of the Sámi were deeply tied to the survival of their culture and traditional livelihoods, reindeer herding in particular. The Sámi informants were unanimous about the need to amend the Reindeer Husbandry Act (848/1990), to better recognize the traditional Sámi ways of herding and knowledge embedded in it. Having strengthened the opportunities of the Sámi to participate in management planning, application of the Akwé: Kon Guidelines is a much welcome development. However, because of the voluntary nature of the Guidelines, their power may be limited in the current situation, where Sámi herders' rights are not settled in national legislation governing reindeer husbandry.
\end{abstract}

Key Words: Akwé: Kon Guidelines; land use planning; Sámi reindeer herding; traditional and local knowledge; wilderness areas

\section{INTRODUCTION}

The Convention on Biological Diversity (UN 1992) was the first international agreement to acknowledge the role and importance of local communities' traditional knowledge in sustainable development. Article 8(j) of the Convention states: "Each Contracting Party shall, as far as possible and as appropriate ... subject to its national legislation, respect, preserve and maintain knowledge, innovations and practices of indigenous and local communities embodying traditional lifestyles relevant for the conservation and sustainable use of biological diversity and promote their wider application with the approval and involvement of the holders of such knowledge, innovations and practices and encourage the equitable sharing of the benefits arising from the utilization of such knowledge innovations and practices."

In Finland, the requirements of Article 8(j) of the CBD are partly fulfilled by application of the Akwé: Kon Voluntary Guidelines (Secretariat of the Convention on Biological Diversity 2004), developed by the parties of the Secretariat of the CBD and first tested in 2013 in the Land Use and Management Plan of Hammastunturi Wilderness Area (Juntunen and Stolt 2013, Metsähallitus 2016). The Guidelines are a protocol "for the conduct of cultural, environmental and social impact assessments regarding developments proposed to take place on, or which are likely to impact on, sacred sites and on lands and waters traditionally occupied or used by indigenous and local communities" (Secretariat of the CBD 2004:5). They are seen as a central instrument in implementation of Article 8(j) of the Convention, specifying as they do that "possible impacts on the respect, preservation, protection and maintenance of traditional knowledge, innovations and practices" should be investigated in land use planning and environmental impact assessments (EIAs; Secretariat of the CBD 2004:12). Name of the Guidelines come from a Mohawk term meaning "everything in creation." This is to emphasize the holistic nature of the Guidelines, which aim to provide "a collaborative framework ensuring the full involvement of indigenous and local communities in the assessment of cultural, environmental and social concerns and interests of indigenous and local communities of proposed developments" (Secretariat of the CBD 2004:1-2; see also Tkarihwaié:ri Code of Ethical Conduct by the Secretariat of the CBD 2011). The Guidelines are now a permanent planning tool of Metsähallitus (Finnish Forest Administration) in land use planning in the Sámi homeland, Sápmi, which comprises the three northernmost municipalities in the Province of Lapland: Ochejohka (Utsjoki), Anaar (Inari), and Eanodat (Enontekiö), and the northern part of the municipality of Soađegilli (Sodankylä).

There are plenty of studies dealing with the use of Indigenous, local, and traditional knowledge in land use planning, decision making, and as part of academic research in Sápmi (e.g., Forbes et al. 2006, Kitti et al. 2006, Riseth et al. 2011, Roturier 2011, Eira et al. 2013, Turi and Keskitalo 2014, Horstkotte et al. 2017). However, even though the Akwé: Kon Guidelines have been in use for several years now, studies addressing their practical application remain scarce (see Juntunen and Stolt 2013, Heinämäki et al. 2014). In this study, we address the use of Akwé: Kon Guidelines and inclusion of traditional and local knowledge (TLK) in land use planning in the municipality of Eanodat in 
Finnish Sápmi where land use and management plans for wilderness and conservation areas have been revised recently. In addition, Eanodat is the first in the world to test the Guidelines in land use planning at the municipal level.

Research literature provides plenty of examples of processes where the recognition of Indigenous, local, and traditional knowledge systems has improved management of ecosystems, natural resources, and biodiversity. Inclusion of diverse ways of knowing in land use planning processes helps understand complex social-ecological systems and brings a social dimension to planning, as the needs, concerns, and world views of local residents are recognized (Heikkilä 2006a, Kitti et al. 2006, Christensen and Granti 2007, Houde 2007, Folke et al. 2011). However, increasing interest in Indigenous peoples' knowledge systems has prompted concerns as well. From Indigenous peoples' point of view, their knowledge is too often required to fit into an existing framework of western ideas to be accepted or considered valuable (Nadasdy 1999, 2005, Armitage et al. 2011). It has been noted that if they are to participate in decision making, Indigenous peoples need to translate their holistic, place-bound knowledge into a format in which it can be heard (Dallman et al. 2011, UNEP 2013). Despite the international acknowledgement, traditional, local, and Indigenous ways of knowing are often given less attention than scientific knowledge in land use planning and governance, one reason being that authorities consider scientific knowledge to be more objective and rational (Peters 2003, Turi and Keskitalo 2014, Johnsen et al. 2015). When dealing with the diversity of knowledge systems in decision-making processes, power issues and asymmetries are always present (Tengö et al. 2014, 2017).

To achieve more equitable and transparent ways of connecting different knowledge systems in policy and planning processes, Tengö et al. (2014) have proposed a multiple evidence base approach (MEB). In the MEB approach, the inclusion of different knowledge systems in planning is based on equity and reciprocity. The approach emphasizes that validation of knowledge should take place within, and not across, the knowledge systems, and acknowledges that Indigenous, local, and traditional knowledge systems have their own internal systems to achieve empirical and social legitimacy. Moreover, the MEB approach notes that, in knowledge policy processes such as planning, management, and governance of resources it is important to differentiate between (a) knowledge integration, (b) parallel approaches, which develop synergies across knowledge systems, and (c) coproduction of knowledge. Knowledge integration is a process whereby locally bound knowledge systems are required to fit into an existing framework defined by an authority. It is a one-way process that has been questioned for a number of reasons, e.g., for exclusion of relevant and locally legitimate knowledge and disempowerment of local communities (Nadasdy 1999, Nakashima and Roué 2002). In a parallel approach, scientific and locally bound knowledge systems are applied separately, but in parallel, with each being legitimate in its own right and within its own context (Berkes 2012). Coproduction of knowledge is a mutual process of knowledge generation, whereby the participants engage in all stages of knowledge generation, including validation, and it is usually applied as part of comanagement of areas and resources (Berkes et al. 2007, Berkes 2009, Dale and Armitage 2011, Tengö et al. 2014, Sandström 2015).
Planning processes and scientific studies incorporating locally bound ways of knowing have been criticized for taking some aspects of TLK better into account than others as well as for treating holistic and complex knowledge systems as a mere collection of environmental data, often leaving cultural and spiritual aspects out (Nadasdy 1999, 2003a, Casimirri 2003, Ludwig 2016). In previous studies, Usher (2000) and Houde (2007) have defined different categories of traditional ecological knowledge that remain unequally represented in planning processes. These include knowledge about the environment (factual observations), knowledge about the past and current use of the environment, management systems, values associated with the environment, and knowledge systems themselves. According to Houde (2007), factual observations and knowledge about the use of the environment are the most comprehensively incorporated into land use planning and governance. On the contrary, knowledge regarding values associated with the environment is rarely included, e.g., in EIAs (Eybursson and Thuestadt 2015, Gondor 2016) and climate change studies (Murphy 2011).

The present study examines (1) process and use of the Akwé: Kon procedure in land use planning in Eanodat as viewed through MEB; (2) inclusion of TLK in recent land use and management plans of wilderness areas as viewed through different knowledge categories defined in previous studies; and (3) challenges identified by local Sámi experts and planning officials in incorporating TLK into land use planning and wilderness area management in Eanodat. To this end, we conducted 13 key informant interviews among local Sámi experts and local planning officials and analyzed recent land use and management plans for wilderness and conservation areas.

\section{Definitions}

We use the term "traditional and local knowledge" (TLK) for local, Indigenous, and place-bound ways of knowing. The terms "traditional knowledge," "local knowledge," and "Indigenous knowledge" overlap and are often used interchangeably in research, land use planning, and management contexts (for definitions, see Appendix 1). "Traditional and local knowledge" also overlaps with the term "practitioners' knowledge," which has been used in research on reindeer herders of northern Fennoscandia (e.g., Forbes et al. 2006, Forbes and Stammler 2009; see Appendix 1). We refer to "traditional" instead of "Indigenous" knowledge because it is the term used in the CBD, which plays an important role in land use planning in the Finnish Sápmi. We are also aware that there are non-Indigenous local communities who have traditional knowledge systems, for example, pastoral farmers in Sweden and Norway (Tunón et al. 2015). However, the Finnish Ministry of the Environment has stated that "knowledge, innovations and practices of indigenous and local communities embodying traditional lifestyles," wording used in the CBD (Article 8(j)), refer exclusively to the Sámi communities, because they are the only ones that embody "traditional lifestyles" in Finland. However, not all knowledge gathered as part of land use planning processes is "traditional" in nature. There is a great deal of knowledge to be tapped, knowledge based on experience and derived from close connection with the surrounding nature yet difficult to place under the term "traditional." In light of these considerations, we have chosen to use the term "traditional and local knowledge" (TLK). 
Fig. 1. Research area and wilderness and conservation areas of Eanodat. The Käsivarsi Wilderness Area consists of 264,950 hectares, and the Saana Area 12,297 hectares. The Pulju Wilderness Area is 69,206 hectares in area, of which $30 \%$ is located in the municipality of Eanodat. Käsivarsi and Saana are pasture areas for the Käsivarsi reindeer herding cooperative. The Pulju Wilderness Area serves as winter pastureland for the Näkkälä reindeer herding cooperative.

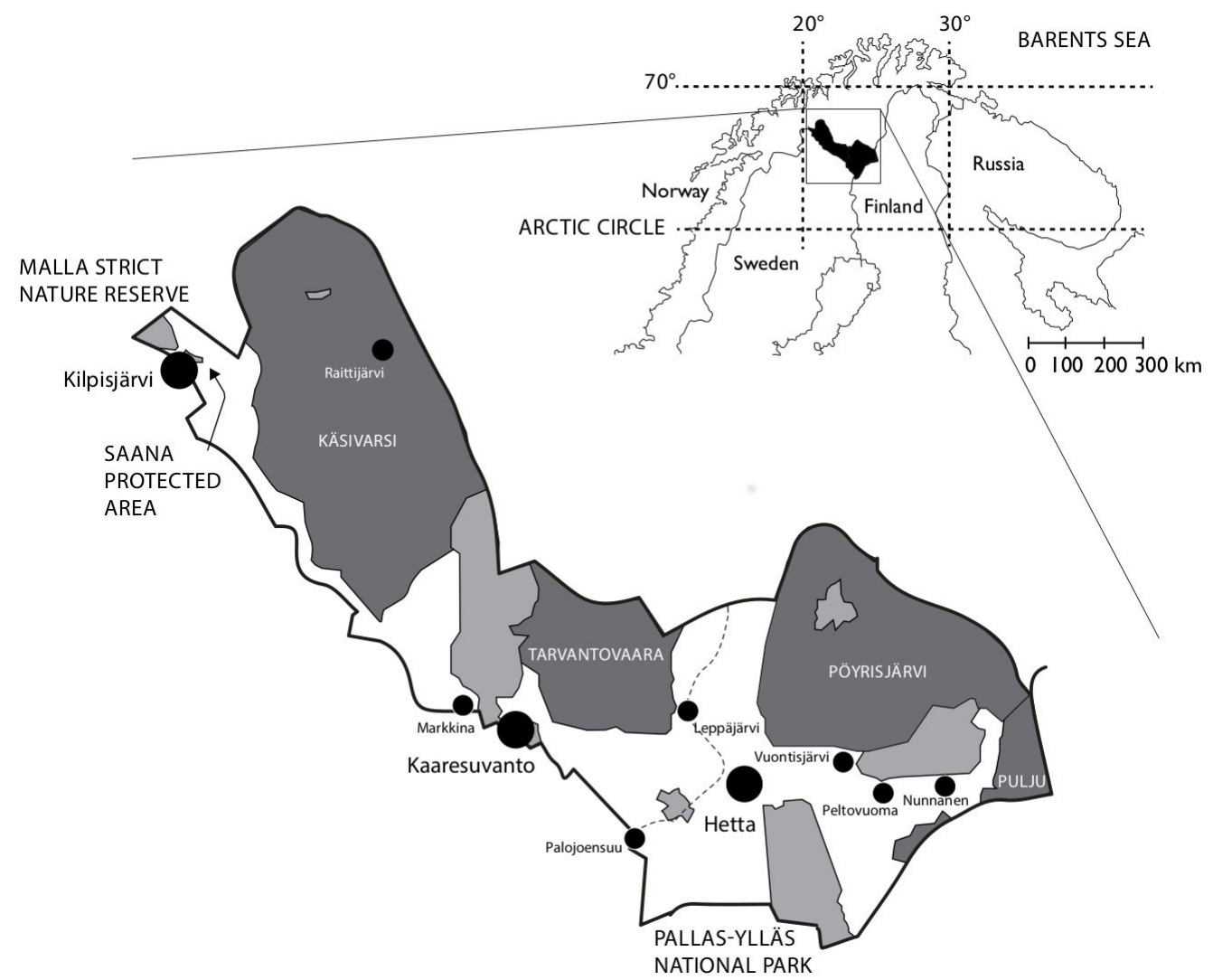

\section{MATERIAL AND METHODS}

\section{Study area}

The municipality of Eanodat is located in northwest Finland along the country's borders with Sweden and Norway in Sápmi (Fig. 1). Eanodat has a population of 1900 residents living in an area of 856400 hectares, most of which is state-owned land. Protected areas cover 65 per cent of the municipality's land area, with these including four Wilderness Areas (Käsivarsi, Pöyrisjärvi, Tarvantovaara and Pulju), the Malla Strict Nature Reserve, the Saana Protected Area, Pallas-Ylläs National Park and numerous smaller conservation areas (Figure 1). Reindeer herding is allowed in wilderness areas and national parks. The aims of the wilderness areas, established in 1991, are to conserve their rugged wild nature, to preserve Sámi culture and livelihoods, and to develop the diverse use of nature and its potential. Metsähallitus, which operates under Ministry of Agriculture and Forestry and in matters concerning nature conservation under the Ministry of the Environment, administers wilderness areas, protected areas, and national parks in Finland.

Management of conservation and wilderness areas under the administration of Metsähallitus is based on land use and management plans. A land use and management plan is a general document outlining the solutions for managing an area of land. The plans encompass the current state of the area, the most important values associated with it, future development, threats and concerns, land use and management goals, and EIA. Land use and management plans are approved by the Ministry of the Environment for a particular area of land and guide its use and management as well as the protection of its natural and cultural heritage for the next 10 to 15 years. An interim audit of the plans is conducted approximately every five years. Throughout the planning process, the general public and stakeholders have opportunities to contribute their points of view and influence the plans. Local participation is fulfilled in public hearings and meetings of stakeholder groups comprising representatives from, e.g., reindeer herding cooperatives, the Sámi parliament, municipalities, village committees, environmental organizations, and tourism entrepreneurs. Today, Metsähallitus applies the Akwé: Kon Guidelines to all land use and management plans in Sápmi.

There are two reindeer-herding cooperatives in Eanodat: Käsivarsi and Näkkälä. Both still mainly follow traditional Sámi ways, with herding based on the siida, a traditional Sámi socioeconomic institution (Lehtola 2004). A siida consists of either a single family or a certain number of households linked 
by kinship, being both a social and a working community (Riseth and Vatn 2009) and can be seen as an endemic model of herding and social organization in Sápmi (Mazzullo 2010). According to the Reindeer Herders' Association (2018), the largest permitted number of reindeer in Käsivarsi is 10,000, and in Näkkälä 8300 . The number of reindeer owners in the Eanodat region is 365 .

\section{Previous land use conflicts in Finnish Sápmi}

There is a long history of land use conflicts in Finnish Sápmi. Building of the Lokka and Porttipahta reservoirs in the 1960s in the southern part of Finnish Sápmi had a devastating effect on local Sámi communities, forcing a shift in reindeer husbandry practices due to destructed pastures (Mustonen et al. 2010). Conflicts between state forestry and reindeer herding have occurred in different parts of Sápmi (e.g., Mustajoki et al. 2011, Mazzullo 2013, Saarikoski and Raitio 2013, Jokinen 2014, Jokinen et al. 2016). One of the most profound ones took place in the municipality of Inari in 2002-2010, when Sámi reindeer herders, together with Greenpeace, were protesting against logging in old-growth forests in areas administered by Metsähallitus. Agreement was reached in 2009 and important reindeer pasture areas were preserved for the next 20 years (Saarikoski and Raitio 2013).

In Eanodat, the role of state forestry is much less important than in Inari, and the land use conflicts have been more profound between nature conservation, tourism, and reindeer herding. The conflict over the Malla strict nature reserve is one of the longest ongoing conflicts in the area. Malla was established in 1916 to protect the unique mountainous ecosystem from deleterious human impacts and to satisfy the needs of science. The area was utilized as a pasture for wild and herded reindeer long before the reserve was founded, but reindeer herding was prohibited in the reserve in 1981 (Heikkinen et al. 2010). The Malla case prompted conflicting views over what counts as the "natural state" of the area. The Sámi herders considered their exclusion from the previously utilized pastures, without any compensation for the losses, a historical injustice and they had difficulty understanding how it is possible to create a genuine natural state in the reserve by excluding reindeer from the historically grazed lands (Heikkinen et al. 2010). On the contrary, conservationists and many scientists saw it necessary to protect the Malla reserve from overgrazing. However, reindeer herds have entered the reserve for many summers since 1998 and, currently, Metsähallitus is leading a process handling the land use and management planning issues of the Malla Park, and the search for a solution to the problem is ongoing (Jokinen et al. 2016).

In 2013, the Ministry of the Environment proposed plans to have more national parks in Finland, and the Käsivarsi area in Eanodat was one of the prime candidates. The Käsivarsi reindeer herding cooperative and the Sámi Parliament favored the establishment of the national park, since national park status was envisioned as enhancing Sámi culture and ramping up nature-based tourism, for example, through restrictions on the use of snowmobiles and other motorized vehicles by tourists (Tuulentie 2017). However, local tourism entrepreneurs, village committees, and municipal decision makers were against the plans, which finally led to nonestablishment of the national park because of what was referred to as strong "local resistance," despite the fact that the local reindeer herding cooperative favored its establishment (see Tuulentie 2017).
At present, the greatest land-use related concern among reindeer herders living in Eanodat is test drilling for ores currently being conducted in the Käsivarsi Wilderness Area, and the possible establishment of a mine there in the future. Despite local resistance, the Finnish Safety and Chemicals Agency granted permission in the summer of 2016 to the Geological Survey of Finland to search for ore in an area that included reindeer pastures of the local Sámi siida. The statements of the Käsivarsi reindeer herding cooperative have emphasized that "searching for ore deposits would hinder Sámi reindeer herders in practicing their traditional livelihoods" (Olsén et al. 2017:71).

In Finland, Sámi rights and ownership to their traditional lands is an open and sensitive political question. It has been under debate during recent decades and continues to influence land use governance issues (Raitio 2008, Nykänen and Valkeapää 2016). Finland has not ratified the International Labor Organization Convention on Indigenous and Tribal Peoples (ILO 169) concerning the rights of Indigenous peoples.

\section{Interviews}

We conducted 13 key-informant interviews between October 2016 and November 2017. Interviews were conducted with local planning officials and Sámi experts involved in land use planning in Eanodat. Two of the officials were working in the infrastructure and environmental division of the municipal administration and five worked for Metsähallitus. The informants working for Metsähallitus were planners or senior planners (4), park manager (1), and a regional director (1). They had all been involved in preparing land use and management plans in the Eanodat area and had work experience ranging from 7 to 27 years. Six of the informants were Sámi experts from local herding communities, and had between 2 and 30 years of experience in participating in land use planning processes and negotiations. The informants were between 32 and 60 years of age, nine men and four women. Following the guidelines on research ethics at the University of Lapland (2009), the respondents were informed before the interviews about the aim of the study and how the interviews were going to be used, and all informants gave their prior informed consent.

The interviews were conducted, recorded, and transcribed by the authors. Two of the interviews were conducted over the phone and were not recorded. Ten interviews were conducted by two of the authors together, and three interviews by one of the authors alone. Excerpts from the 11 transcribed interviews presented in the text below are translations from Finnish, the language of the interviews. The interview questions are presented in Appendix 2. The informants were coded with numbers from 1 to 13, followed by LHC (local herding community), MH (Metsähallitus), or MP (municipality) to indicate where they worked. The interviews were analyzed using qualitative thematic content analysis (Tuomi and Sarajärvi 2009) through which we sought to gain an interpretive understanding of the material. When analyzing the interviews, we concentrated on four central themes that emerged from the theoretical background (Tengö et al. 2014) and the aims of our study: (1) the impacts of the Akwé: Kon Guidelines; (2) challenges in incorporating TLK into land use planning and wilderness area management; (3) mismatch between knowledge systems; (4) knowledge validation. 


\section{Analyses of land use and management plans}

We analyzed three recent land use and management plans for wilderness and protected areas: Land Use and Management Plan for the Käsivarsi Wilderness Area (Metsähallitus 2017a), Land Use and Management Plan for the Saana Area (Metsähallitus 2017b), and Land Use and Management Plan for the Pulju Wilderness Natura Area (Metsähallitus 2018). The Akwé: Kon Guidelines were applied in all plans. The plans for Saana and Käsivarsi were still unpublished at the time of analysis. The plan for Pulju was awaiting confirmation by the Ministry of the Environment when analyses were carried out, and was published in January 2018.

We evaluated how TLK of different categories (I-IV) defined in previous studies (Usher 2000, Houde 2007) was included in these plans. We chose four categories whose role we examined: Category I: Knowledge about the environment, Category II: Knowledge about the past and current use of the environment, Category III: Management systems, and Category IV: Values associated with the environment. We used qualitative content analysis with deductive category application, and used the four TLK categories (Usher 2000, Houde 2007) as previously formulated, theoretically derived aspects of analysis. We then sought from each land use and management plan the descriptions and expressions that represented these aspects.

\section{LEGISLATIVE BACKGROUND OF LAND USE PLANNING IN SÁPMI}

The most important piece of legislation controlling land use, spatial planning, and construction in Finland is the Land Use and Building Act (Ministry of Justice 1999). Its aim is to "organize land use and building to create the basis for high-quality living environments, to promote ecologically, economically, socially and culturally sustainable developments, to ensure that everyone has the chance to participate in open planning processes, to guarantee the quality of openly publicized planning decisions and participatory processes, and to ensure that a wide range of planning expertise is available."

In the Sámi homeland, legislation on the rights of Sámi as an Indigenous people plays a central role in land use planning processes. Since 1995, the Constitution of Finland has included provisions guaranteeing the Sámi cultural and linguistic autonomy and the right to maintain their own culture and language. The Act on the Sámi Parliament (Ministry of Justice 1995:3) requires authorities to negotiate with the Sámi Parliament in "all far-reaching and important measures which may directly and in a specific way affect the status of the Sámi as an indigenous people."

A similar obligation to consult is required by the Reindeer Husbandry Act (Ministry of Agriculture and Forestry 1990:17): "when planning measures concerning State land that will have a substantial effect on the practice of reindeer herding, the State authorities must consult the representatives of the reindeer herding cooperative in question." In Finland, unlike in Sweden and Norway, reindeer herding is not an exclusively Sámi livelihood. The approach in the Reindeer Husbandry Act (Ministry of Agriculture and Forestry 1990) is a general one and does not recognize reindeer herding as a cultural right of the Sámi (see Heinämäki et al. 2017).
Sámi rights to traditional livelihoods are recognized in the Mining Act (Ministry of Justice 2011:15), which states, "An exploration permit, mining permit, or gold panning permit must not be granted if activities under the permit ... alone, or together with other corresponding permits and other forms of land use would, in the Sami Homeland, substantially undermine the preconditions for engaging in traditional Sami sources of livelihood or otherwise to maintain and develop the Sami culture."

Another key piece of legislation regarding Sámi rights is the Act on Metsähallitus (Ministry of Justice 2016, Heinämäki et al. 2017). The Act requires that management, use, and protection of natural resources administered by Metsähallitus and located in the Sápmi must be reconciled with the practice of Sámi culture. Under the Act, the forestry operations of Metsähallitus have been transferred to a limited liability company for forestry, which will be fully owned by the state. National parks, wilderness areas, and other nature conservation areas will continue to be used because they are at present administered by the Ministry of the Environment. The CBD (UN 1992) plays an important role in land use planning in the Sápmi. Since 2013, the Akwé: Kon Guidelines have been applied by Metsähallitus and to some extent by municipalities, the aim being to fulfil the requirements of the CBD to "respect, preserve and maintain knowledge, innovations and practices of indigenous and local communities embodying traditional lifestyles" (UN 1992:Article 8(j)).

\section{AKWË: KON PROCESS}

In 2009, the Ministry of the Environment in Finland appointed a national group of experts on article 8(j) of the CBD, with the task of coordinating the measures concerning the traditional knowledge of Indigenous peoples as outlined in the Finnish strategy and action plan for the conservation and sustainable use of biological diversity for 2006-2016 (Juntunen and Stolt 2013). One of the objectives of the group of experts was to provide recommendations for the application and implementation of the $\mathrm{CBD}$, in particular its article 8(j). In their final report, the group presented that the Akwé: Kon Guidelines should be applied in land use planning and management in Sápmi, in accordance with the national legislation. In 2010, Metsähallitus and the Finnish Sámi Parliament initiated preparations for the application of the Guidelines and reviewed their applicability to the management and land use planning system of Metsähallitus. The Sámi Parliament and Metsähallitus cooperated in piloting the application of the Akwé: Kon Guidelines by preparing a management and land use plan for the Hammastunturi Wilderness Area (Juntunen and Stolt 2013). After that, the Guidelines were adopted as a permanent protocol of Metsähallitus in wilderness and conservation area planning.

The Akwé: Kon Guidelines require representatives of Indigenous people to participate in all stages of the management and land use planning process, from planning to implementation and monitoring (Juntunen and Stolt 2013, Metsähallitus 2016). This is the main improvement provided by the application process of the Guidelines. Previously, the Sámi Parliament has assessed the impacts of management and land use plans after the plan has been completed. In that case, assessments of environmental impacts were already included in the plans, and the Sámi Parliament then carried out an assessment of the impacts on Sámi 
Table 1. Summary of the evaluation of how different traditional and local knowledge (TLK) categories were taken into account in the land use and management plans of the Käsivarsi Wilderness Area, Saana Area, and Pulju Wilderness Area. The text in each cell describes which data from each TLK category was included and what kind of lack of knowledge was cited in the plans. For a more detailed description of categories, see Material and methods. CHS = Cultural heritage sites. A siida is a traditional Sámi socioeconomic unit.

\begin{tabular}{|c|c|c|c|}
\hline $\begin{array}{l}\text { TLK category/Land use } \\
\text { plan }\end{array}$ & Käsivarsi Wilderness (2017) & Saana Area (2017) & $\begin{array}{l}\text { Pulju Wilderness Natura } \\
\text { Area (2018) }\end{array}$ \\
\hline $\begin{array}{l}\text { I Knowledge about the } \\
\text { environment }\end{array}$ & Evaluation of threats for Sámi culture & Evaluation of threats for Sámi culture & Not identified \\
\hline $\begin{array}{l}\text { II Knowledge about the } \\
\text { use of areas }\end{array}$ & $\begin{array}{l}\text { Reindeer herding structures on a map, areas used } \\
\text { by each siida }\end{array}$ & $\begin{array}{l}\text { Reindeer herding structures, areas used } \\
\text { by each siida }\end{array}$ & $\begin{array}{l}\text { Reindeer herding structures } \\
\text { on a map }\end{array}$ \\
\hline III Management systems & Reindeer herding as cultural livelihood & Reindeer herding as cultural livelihood & $\begin{array}{l}\text { Reindeer herding as cultural } \\
\text { livelihood }\end{array}$ \\
\hline $\begin{array}{l}\text { IV Values about the } \\
\text { environment }\end{array}$ & $\begin{array}{l}\text { Importance of cultural landscape, inventories of } \\
\text { CHS }\end{array}$ & $\begin{array}{l}\text { Importance of cultural landscape, } \\
\text { inventories of CHS }\end{array}$ & $\begin{array}{l}\text { Importance of cultural } \\
\text { landscape }\end{array}$ \\
\hline $\begin{array}{l}\text { Lack of knowledge } \\
\text { mentioned }\end{array}$ & $\begin{array}{l}\text { Category III: Sámi reindeer herding, Category } \\
\text { IV: Cultural heritage }\end{array}$ & Category III: Sámi reindeer herding & Not identified \\
\hline
\end{tabular}

culture after the fact (Juntunen and Stolt 2013). Now, when the Akwé: Kon Guidelines are applied, Sámi representatives participate from the onset, and the impact assessment process is continuous. In practice, at the beginning of the planning process, the Sámi Parliament appoints the Akwé: Kon working group. The members of the working group, usually five members, are users of the area under planning and holders of traditional knowledge, and should represent various age and language groups as well as genders. Their work is funded by the State, through resources appointed to Sámi Parliament and Metsähallitus. The tasks of the working group include, e.g., preparing reports on the Sámi customary use of natural resources, on Sámi cultural heritage, and on the significance of the area to Sámi culture, descriptions of the Sámi reindeer herding in the given area, defining values and threats as well as assessing the impacts of the plan on the Sámi culture (Juntunen and Stolt 2013, Metsähallitus 2016).

\section{RESULTS}

\section{Types of TLK represented in land use and management plans}

Table 1 presents a summary of the results of our evaluation on how the four categories of TLK were taken into account in the land use and management plans studied. This question was also discussed with the informants, with their being asked to evaluate which kind of knowledge (scientific, local, traditional, and in what context) is the most important or has the biggest impact on planning decisions.

TLK Category I, Knowledge about the environment, refers to factual or rational knowledge about the environment, which includes specific observations about animal distributions, abundance, behavior, habitats, and species interactions; historical trends in spatial and population patterns; statements about cause and effect; and impact predictions (Huntington 2000, Turner et al. 2000, Nadasdy 2003b). This type of TLK is usually best compatible with the knowledge used by resource management authorities (Nadasdy 2003a, b, Houde 2007, Berkes 2012). In planning land use and management of wilderness and conservation areas, knowledge regarding natural values and observations on species distribution, abundances, and the like obviously plays a central role.
According to our informants (MH 1, 2, 3) and the land use and management plans analyzed, Category I knowledge is always collected by scientists, except that the locals are heard and the Akwé: Kon groups take part in evaluating impacts and threats. The land use and management plans for the Käsivarsi Wilderness Area and the Saana Area mentioned the following threats to Sámi culture in the areas: lack of knowledge regarding Sámi culture and the siida system, growing tourism and disturbance due to transport and/or off-road traffic, decrease in the area of reindeer pastures due to other land uses and growing infrastructure, and the effects of climate change (Metsähallitus 2017a, b). The Käsivarsi plan also noted concerns regarding a loss of Sámi place names, possible mining activities, increasing numbers of predators, and overfishing (Metsähallitus 2017a). The Käsivarsi Wilderness Area and the Saana Area are both popular among tourists and thus a number of threats were identified in these areas. In the Pulju Wilderness Natura Area Plan, no particular threats to Sámi culture were cited because the area is remote and mainly used by locals for hunting, fishing, and reindeer herding (Metsähallitus 2018). Also seen as a threat to the continuity of traditional Sámi livelihoods was the lack of broad negotiation rights of siidas (Metsähallitus 2017a). In the Käsivarsi and Saana plans, the Akwé: Kon groups suggested that siidas should be better included in land use planning negotiations with herding cooperatives (Metsähallitus 2017a, b).

According to our interviews, TLK regarding the current use of areas (Category II) is the type of knowledge predominantly collected in public hearings and stakeholder meetings; it was considered pivotal because land use management and planning

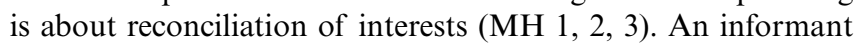
working as a planner described how different types of TLK are represented in planning processes:

Ninety per cent of the knowledge collected as part of planning is connected to how areas are being used and interests related to the areas. That is the most important information in land use planning; however, we would need more information about the historical use of areas, and about places important for local people because of natural, historical, or cultural values. This kind of 
cultural knowledge should be collected more; it has a value in its own right. It is also a matter of preserving the cultural heritage. (MH 1)

One of the aims of wilderness areas is to preserve Sámi culture and livelihoods. Accordingly, all land use and management plans have a chapter for reindeer herding, including information on reindeer herding structures (e.g., pastures, rutting and calving areas, pasture rotation, boundaries of herding cooperatives, and cabins), the number of reindeer allowed for each herding cooperative, impacts of predators, and the quality of pastures. With regard to Sámi herding system, the Käsivarsi and Saana plans are more detailed than the Pulju plan, describing the pasture and calving areas of each siida in the area.

In the case of management systems (Category III), the specific characteristics and cultural meanings of Sámi reindeer herding are acknowledged in all plans, stating that "Sámi reindeer herding has maintained its unique and special characters even though there are attempts in reindeer herding legislation to conform reindeer herding" (Metsähallitus 2017a:55, Metsähallitus 2017b:47, 2018:35) and "Sámi reindeer herding is clearly a cultural livelihood, in which passing on the culture and livelihood to the next generation is of paramount importance" (Metsähallitus 2017a:55, Metsähallitus 2017b:47, 2018:34). However, Sámi informants were concerned about the lack of knowledge regarding the specific characteristics of Sámi reindeer herding (LHC 7, 9, 10, 13), as seen in the following excerpts:

Officials, as well as locals, should have more knowledge about the Sámi reindeer herding system. I believe that here in Eanodat our herding cooperatives are closest to the old way of herding. We still have the siida system. (LHC 9)

\section{Finland should acknowledge Sámi reindeer herding. It is very different from the so-called Finnish way. They are not even comparable. (LHC 7)}

Similarly, the Akwé: Kon groups of Käsivarsi and Saana plans stated that the lack of specific knowledge regarding Sámi reindeer herding, such as the siida system, "can lead to decisions that are harmful for the practice of the livelihood" (Metsähallitus 2017a, $b: 54)$.

Category IV, values associated with the environment, consists of peoples' values and preferences, that is, what they consider significant or valued components of the environment. For Indigenous peoples, spirituality and culture play a strong role in determining such values. For example, this element of TLK includes moral and ethical statements about the environment and about the relationships among humans, animals, and the environment, or the "right way" to do things (Eybursson and Thuestadt 2015). To some extent values are connected to the uses of the environment. In all of the land use and management plans we examined, knowledge about values is discussed in the context of cultural landscapes: "The Sámi cultural landscape encompasses traditional use of natural resources, place names and physical features, as well as stories, sacred sites, history, values, customary rights and traditional knowledge" (Metsähallitus 2017a:22, Metsähallitus 2017b:19, 2018:23). Here, values and traditional knowledge are considered separately, whereas cultural landscapes are seen as connecting different aspects of historical and spiritual values, including traditional land use. The Land Use and Management Plan of the Käsivarsi Wilderness Area expressed concern over the lack of knowledge about the area's cultural heritage: "The lack of knowledge regarding Sámi culture and sacred sites among tourists and other users of the area can lead to unintended harmful actions and therefore be a threat to the preservation of the culture" (Metsähallitus 2017a:54). In line with this, some of the informants pointed out that more efforts should be made to collect knowledge about the cultural heritage and Sámi culture in general (MH 1, 4, LHC 8, 9). Inventories of places with cultural heritage values were carried out in Käsivarsi in 2012 and 2014 and in the Saana Area in 2010-2011, but only a small part of what is a vast area could be covered (Metsähallitus $2017 a, b)$. The inventories targeted the most vulnerable areas, ones facing pressure from different land uses, the aim being to protect the cultural heritage of these places in particular. According to traditional records, there are several sacred sites in the area, but the exact locations of only few of them are documented. Saana Fell is a well-known sacred site of the Sámi people. It should be however noted here that discussion of whether the locations of Sámi sacred sites should be documented and whether this information should be open access is ongoing in Finland at large and among Sámi communities in the Nordic countries. The Finnish National Board of Antiquities (https://www.kyppi.fi/ palveluikkuna/mjreki/read/asp/r_default.aspx) maintains an open-access database of antiquities, which includes the locations of many sacred sites of the Sámi. Many people are concerned that sacred places will lose their value and vanish if exposed, but the view has also been put forward that protecting sacred sites from unintended destruction is not possible if their locations are not known (Äikäs 2013, see also Norberg and Fossum 2011).

The use of Akwé: Kon procedure in land use planning in Eanodat The informants had varying views regarding the impacts of the Akwé: Kon protocol on land use planning. Some saw the Guidelines as an important and useful element in planning $(\mathrm{MH}$ 2, LHC 12,13) while others felt it was too early to assess the effects of what at the time of conducting the interviews was a rather new protocol in Eanodat area (MH 4, MP 5, 6, LHC 7), or said that they had not been involved in the work of the Akwé: Kon groups enough to answer (MH 1, LHC 9). According to one informant, the Akwé: Kon protocol has improved the knowledge base and knowledge-gathering processes of land use plans because the local Sámi can participate throughout the process, different age and gender groups are represented, and, as a result, a greater diversity of issues is brought up and taken into consideration (LHC 12). Another informant pointed out that different groups, such as craftsmen and women, fishers and reindeer herders, should all be represented in negotiations in order to better include Sámi traditional knowledge in planning (LHC 13). In the same vein, one of the planners at Metsähallitus commented that it would be important to have more old and young people and women to participate in planning processes, noting, however, reaching citizens who do not take part in public hearings or stakeholder group meetings would require more resources ( $\mathrm{MH} 1)$. In a relevant finding, Olsén et al. (2017) note that the resources allocated for different Akwé: Kon groups vary between planning processes, which impacts the results, that is, the kind of knowledge collected and integrated into land use plans.

The Akwé: Kon Guidelines have also been applied by the municipality of Eanodat to wind power planning. At the time the interviews were conducted, wind power planning had been 
suspended, but the informants described how the Akwé: Kon protocol was applied when the planning started. The municipality has a different approach to the Akwé: Kon protocol compared to that of the Ministry of the Environment and Metsähallitus. The Ministry has made its decision on the grounds that "knowledge, innovations and practices of indigenous and local communities embodying traditional lifestyles" as worded in the CBD refer exclusively to the Sámi, because theirs are the only communities that embody "traditional lifestyles" in Finland (UN 1992:Article 8(j)). However, in the context of municipal planning in Eanodat, the expression "indigenous and local communities" is understood to refer to all local communities (MP 5, 6). Accordingly, in the abovementioned context to wind power planning, the Akwé: Kon groups consisted of local people from many different groups representing a variety of interests.

\section{Challenges in incorporating TLK into land use planning}

\section{Legislative challenges}

Sámi experts cited legislation as one of the biggest challenges in relation to the incorporation of TLK into land use planning, the particular concern being that the Sámi siida system is not recognized in the Reindeer Husbandry Act (Ministry of Agriculture and Forestry 1990). The approach adopted in the Act, which is general and does not recognize Sámi reindeer herding as a unique system and as a cultural right, is problematic from the perspective of Sámi herders (Heinämäki et al. 2017, Näkkäläjärvi and Jaakkola 2017, Jaakkola et al. 2018). The Sámi informants indicated that understanding the herding system and its particular features is a central question in land use planning and management:

The Reindeer Husbandry Act does not recognize the Sámi reindeer herding system. ... The law should be opened up and amended. (LHC 9)

To better consider reindeer herders' views and knowledge, the Reindeer Husbandry Act should be amended. (LHC 12)

The Sámi reindeer herding system should be recognized [in the law]. Another problem is that the [national] Reindeer Herders' Association does not recognize the Sámi reindeer herding system. (LHC 10)

The Sámi informants considered the Reindeer Husbandry Act (Ministry of Agriculture and Forestry 1990) to be the most important legal instrument protecting traditional livelihoods and the knowledge embodied in them. One noted how the Reindeer Husbandry Act hampers the effect of international conventions such as the CBD:

\section{The Finnish Reindeer Husbandry Act does not recognize Sámi reindeer herding [the siida system]. It is like it does not exist. Finnish reindeer herding is so strong in the law. ... These conventions are not useful as long as the situation is like this. It would be very important to recognize Sámi reindeer herding in the law. (LHC 7)}

Within the Sámi community, there are also concerns over the new Act on Metsähallitus (Ministry of Justice 2016) and its effects on reindeer herding (see also Heinämäki et al. 2017). The Act does not include full protection of Sámi lands from the adverse effects of activities controlled by Metsähallitus (Aslaksen et al. 2017).
This has prompted concerns over the weakening of Sámi rights and over increased pressures on land use in the Sápmi. These worries were expressed by the Sámi informants, and the preparation of the law was seen as having ignored the views of local Sámi. The United Nations Human Rights Council has noted that preparation of the Act on Metsähallitus did not solicit the Sámi's free, prior, and informed consent, a procedure to which they are entitled as an Indigenous people (Heinämäki et al. 2017).

Documenting and mapping TLK

Officials working for the municipality and Metsähallitus in Eanodat also cited legislation as the most important factor directing and regulating their work and land use planning in general. However, they did not mention any legislative challenges that might affect the incorporation of TLK into land use planning. Officials drew attention to several practical and technical challenges, such as the need to make TLK more spatially explicit:

Quite a small amount of the feedback we get is localized or spatially explicit. Exclusively verbal feedback can be difficult to integrate into planning. (MH 2)

Geographic information is the most relevant for us. It should be geographic information gathered into one system or database, as well as information regarding valuable places, fishing, hunting and cloudberry-picking places, places that have cultural heritage values, places where relatives have resided, pasture areas, areas important in different seasons and so on. (MH 1)

Another problem pointed out by most of the officials was that the knowledge collected in land use planning processes often has to be reworked and fit into a database, which is not the best way to present context-specific knowledge of a narrative nature. This mismatch between system requirements and the nature of TLK was brought up by two informants:

Our planning system is in written form, and [locall traditional] knowledge in oral. It can be difficult to recast in the form of a statement.... Or it could be that a lot of material has been produced, but because our planning system is a database, we have to rework the information and present it in an abstract form. And even though it [the collected knowledge] impacts on the planning decisions we make, there is a loss of information. (MH 3)

We have always had this goal that in our land use and management plans we have a chapter for TK or, say, for the cultural and historical use of areas, but maybe recently there have been fewer resources for that. The reason could also be that our management plans today are Excel based. (MH 4)

Knowledge validation

When we asked the informants to evaluate what kind of knowledge has the biggest impact on planning decisions, most considered the question a difficult one. However, it prompted considerations regarding the legitimacy of knowledge. One point raised was the concreteness of knowledge:

Knowledge that is based on facts /has the biggest impact ]. It needs to be concrete; one has to be able to 
Table 2. Different challenges in incorporating traditional and local knowledge (TLK) into land use planning and possible solutions.

\begin{tabular}{llll}
\hline \hline Challenge & \multicolumn{2}{c}{ Reference } & Possible solution/needed development \\
\cline { 2 - 3 } & Interviews & Literature & More knowledge sharing \\
\hline Lack of knowledge: Sámi herding system & Local Sámi & Olsén et al. (2017) & More documentation of TLK \\
Lack of knowledge: cultural heritage & Authorities & Metsähallitus (2017a) & Amending of Reindeer Husbandry Act \\
Sámi herding system not recognized & Local Sámi & Heinämäki et al. (2017) & Use of locally governed PGIS systems to document TLK \\
TLK not spatially explicit & Authorities & & Application of collaborative learning processes \\
Mismatch with planning systems & Authorities & Dallman et al. (2011) & Broader negation rights for Sámi siidas \\
Power imbalance & Local Sámi & Metsähallitus (2017a, $b)$ &
\end{tabular}

demonstrate it to others and to clarify the impacts of a certain plan on values or the use of the area. (MP 5)

All information on the focal area [has an impact]; it is important to collect all kinds of knowledge. But it needs to be justified, to be concrete. Values connected to places have to be justified. (MH 1)

Previous studies have noted that incorporation of TLK into decision making and management processes is often implemented through validation (evaluation) processes that operate on terms set by science (Gratani et al. 2011, Tengö et al. 2012, see also Agrawal 2014). The MEB approach emphasizes that, when different ways of knowing are included in planning, governance, and scientific studies, the validation of knowledge should take place within each knowledge system, and acknowledges that TLK systems have their own, inner systems for achieving empirical and social legitimacy (Tengö 2014). Regarding legitimacy and validation, one informant with long experience in regional land use planning described a learning process that has taken place in regard to how the "weight of facts" is considered:

\section{When we were first learning about participatory planning in the beginning of the 1990s ... it was a lot about facts; we thought that there had to be a large number of facts and it was, in way, a matter of arguing about who had the most correct or most legitimate facts. But that does not work. For a long time now, at least here in Lapland, our starting point has been to find out what the most important issues for different groups are and then to try to find solutions. ... It is not about the weight of facts, but more about how people feel about their voices and concerns being heard. ... In land use planning, mutual understanding cannot be reached by presenting only numbers and facts. (MH 11)}

The Sámi informants emphasized the difference between being heard and having an impact on the decisions made and between recognition of knowledge and the impacts of knowledge. The Sámi informants noted that it depends very much on the particular case whether their views have an impact on the decisions made. The information gathering process and knowledge base for recent land use and management plans of Metsähallitus were seen as rather good by some of the informants ( $\mathrm{LCH} 8,10,12)$. At the same time, however, test drilling for ores was cited as an example of a land use issue on which the views of the local Sámi are not having any impact at all (LHC 7, 8, 9,1 0, 12). In the words of one informant: "we are not heard when there is big money involved" (LHC 7). The possible construction of a mine was seen by the Sámi informants as the single most ecologically and culturally threatening foreseeable project in the area, one that would be "the end of Sámi reindeer herding in the area" (LHC 7, 8, 9, 10, 12). The Sámi are a minority in Eanodat, accounting for one-fifth of the municipality's 1900 inhabitants. They are likewise a minority in the Reindeer Herders' Association, a national body that is an important administrative link between ministries and reindeer herders (Heikkilä 2006b). These power imbalances make it particularly difficult for the Sámi to have a real impact on planning and area management decisions. The challenges and possible solutions in incorporating TLK into land use planning are presented in Table 2 .

\section{DISCUSSION}

TLK in land use planning in Eanodat: challenges

The number of informants in our study was rather small, and thus the results should not be extrapolated for the whole Sápmi area. However, some important points came to the fore, in particular regarding the challenges in incorporating TLK into land use planning, which can be discussed in the light of previous research. The challenges that officials identified are to some extent similar to those reported in different cases of community-based environmental monitoring in Canada: shortage of resources, potential incompatibilities between traditional and scientific approaches, challenges in documenting knowledge, and discrepancies in defining the meaning and implications of the knowledge collected (e.g., Peters 2003, O'Flaherty et al. 2008, Lefler 2010). Yet, the challenges identified by the officials are mostly practical in nature, while the obstacles pointed out by local Sámi experts are connected to the survival of the people's livelihood and culture, traditional Sámi reindeer herding. Sámi informants were unanimous regarding the need to amend the Reindeer Husbandry Act (Ministry of Agriculture and Forestry 1990), which in its current form does not recognize the distinct form of Sámi reindeer herding. These demands are not new, and have been brought up in several earlier studies (e.g., Sillanpää 1994, Magga 2003, Heikkilä 2006a, Müller-Wille et al. 2006).

In Finland, approximately one-third of reindeer herders are Sámi, and consequently, the central administration of reindeer herding is dominated by Finnish ways of thinking (Heikkilä 2006b). In this respect, Finland is different from Norway and Sweden, where Sámi represent a solid majority in reindeer herding. In regard to their most important resources, pastures and reindeer, Sámi herders are dependent on the decisions made by external authorities, who determine, among other things, the number of animals permitted within each herding district and the right to 
exclude or restrict competing forms of land use (Heikkilä 2006a). Even today, despite developments such as application of the Akwé: Kon Guidelines, encroachments on traditional Sámi lands and restrictions on Sámi self-determination continue to pose serious challenges to the people's traditional livelihoods (Aslaksen et al. 2017). In the northern regions of Norway, Sweden, and Finland, the history of the Sami has been shaped by a continuous loss of lands and natural resources. This applies especially to land that is essential for reindeer husbandry. For the Sámi, the continuation of reindeer herding is directly related to their Indigenous rights to land and water, sovereignty issues, and the secured use of resources in their homeland (Müller-Wille et al. 2006). It has been stated in different studies that traditional livelihoods, and the traditional knowledge embodied in them, can only be safeguarded through future clarification and protection of Sámi land and resource rights (e.g., Müller-Wille et al. 2006, Carstens 2016). The Sámi informants emphasized the need for legal recognition of the siida system. This has been done in Norway, where the Reindeer Husbandry Act was revised in 2007 and now gives siidas a legally acknowledged and a more central role in local reindeer management (Turi and Keskitalo 2014). In Finland, the Reindeer Husbandry Act (Ministry of Agriculture and Forestry 1990) came into force before the Constitution of Finland (1995) was amended to include provisions guaranteeing the Sámi cultural and linguistic autonomy and the right to maintain their own culture and language. Therefore, the Act does not ensure the rights of Sámi people to practice their culture as set in $17 \S 3$ of the Finnish Constitution (Heinämäki et al. 2017). The struggle to be officially recognized by the state through legislation is described in the work of Sillanpää (1994) in the form of quotes from interviews conducted shortly after the Reindeer Husbandry Act came into force: "The Sámi has suddenly become little more than a tourist in his homeland. This has been taking place for generations and continues to take place today. This is particularly hard on Sámi who do not own their own land and are not recognized under the Reindeer Herding Act" (Sillanpää 1994:163).

\section{Knowledge mismatch?}

Previous studies from Sápmi in Norway and from Nunavut, Canada, have noted that values associated with the environment are rarely included in EIA (Eybursson and Thuestadt 2015, Gondor 2016). The lack of knowledge regarding the Sámi cultural heritage and cultural values, noted in the Land Use and Management Plan for the Käsivarsi Wilderness Area (Metsähallitus 2017a) and brought up by some of the informants, is in line with these findings. Knowledge embedded in cultural landscapes, including knowledge of the past use of areas, is often transmitted from generation to generation in the form of narratives (Cruikshank 1998, Usher 2000, Callaway 2004). The knowledge collected during land use planning processes, however, has to be reworked to meet the requirements of databases, which is not the best way to present context-specific knowledge of a narrative nature. It has been argued that if it is to be taken into account in land use planning, TLK needs to be coded and simplified to meet the requirements of a planning system (Dallman et al. 2011, UNEP 2013). However, simplifying and coding carry a risk that knowledge, traditional knowledge in particular, may be taken out of context and that the cultural and historical connections of the knowledge will be lost (Eybursson and Thuestadt 2015). This mismatch between system requirements and the nature of TLK, as well as the need to make TLK spatially more explicit, were brought up by the officials interviewed.

Participatory geographic information systems (PGIS) provide a tool to make local knowledge more spatially explicit, and have been widely applied to engage local people in planning processes, to map local values and to identify the spatial dimensions of social and cultural landscapes (e.g., Alessa et al. 2008, Brown and Weber 2012, Brown and Kyttä 2014, Heikkonen 2014). In Sápmi, these methods have been used for, among other purposes, documenting TLK to guide archaeological studies (Barlindhaug 2013), to improve dialogue and knowledge coproduction in land use planning (Sandström 2015), and to integrate Indigenous and traditional knowledge into EIA (Eybursson and Thuestadt 2015). However, participatory mapping does not necessarily succeed in including the views of Indigenous communities in planning (Barlindhaug 2013) and may poorly express the content of knowledge systems that are largely transmitted through oral and nonverbal means (O'Flaherty et al. 2008). Moreover, it is not sufficient that Indigenous communities merely document and share the information they hold; they need to be able to participate in planning decisions in ways that enable them to actuate their knowledge (Davidson-Hunt and O'Flaherty 2007, O'Flaherty et al. 2008). The ethics of Indigenous mapping are still being explored because maps often represent prevailing power structures. Many questions, brought up previously, e.g., by Rambaldi et al. (2006), are still to be addressed when PGIS methods are applied. These include, for example, the following: Whose voice counts in the mapping process? Whose reality, categories, perceptions, truth, and logic are expressed? Who owns the output? Who is empowered and who is disempowered? The Sámi have emphasized that their traditional knowledge is collectively owned by local communities (Henriksen 2011), and according to the Ottawa Traditional Knowledge Principles of the Arctic Council: "Traditional Knowledge is the intellectual property of the indigenous knowledge holders" (Arctic Council 2015:2). The questions of who has the right to map and use that knowledge and who is empowered to grant consent to these actions feature prominently when participatory mapping methods are applied.

Because of its oral and practical nature, TLK may be difficult to concretize (e.g., Gearheard et al. 2013, Olsén et al. 2017). Some aspects of TLK may be overlooked in land use planning because the knowledge is not considered concrete or a fact. However, even though value-choice issues and planners' own philosophical and political values are inevitably involved in planning processes (Kiernan 1983), the ways to perceive and approach knowledge, facts and truth, are not immutable. This is shown in the quote from an informant with long experience in regional land use planning. "When we were first learning about participatory planning in the beginning of the 1990 s ... it was a lot about facts; we thought that there had to be a large number of facts and it was, in way, a matter of arguing about who had the most correct or most legitimate facts. But that does not work."

Earlier studies have discussed how the ways in which people perceive the nature of knowledge influence their opinions regarding whether there is a universal truth, what counts as 
evidence, and which forms of knowledge are considered valid (Firestone 1987, Dyson and Brown 2006, Raymond et al. 2010). As one example, the Sámi ways of knowing regarding reindeer rangeland have been documented in significant detail in different parts of their homeland, but overlooked in administration, because the administration's criteria for the carrying capacity of rangeland allow only certain indicators, such as remotely sensed lichen and green vegetation cover/biomass (e.g., Kitti et al. 2006, Roturier 2011, Horstkotte et al. 2017).

As Johnsen et al. (2015) have noted, facts and knowledge are always situated and partial, a characteristic often prompting struggles over their legitimacy. Indigenous knowledge holders have asserted that, despite having their own types of knowledge, epistemologies, and truth claims, they are often forced to justify their perspectives using scientific discourse (Murphy 2011). There are attempts toward equality of knowledge systems in local land use planning and global assessment programs, one of these being the MEB approach (Tengö et al. 2014), which has been applied to the work of Intergovernmental Science-Policy Platform on Biodiversity and Ecosystem Services (IPBES) and the CBD to connect diverse knowledge systems in a transparent and equitable manner. Another example is a collaborative learning process described by, among others, Sandström et al. (2012) and Sandström (2015), which has been applied in Sápmi in Sweden, and in which reindeer herders and land use officials visit and walk together over the herding territories and agree upon terms of reference for land cover classification and planning. The Akwé: Kon Guidelines, in principle, are a similar attempt.

An interesting case with regard to Johnsen's (2015) note mentioned above is the application of the Guidelines by the municipality of Eanodat to the planning of wind farms. In their planning process, the expression "indigenous and local communities" was understood to refer to all local communities, which can be seen as an attempt to modify the principles set out in the Guidelines. The former manager of the municipality argued strongly that the Guidelines should be extended to include other small local communities and to be applied in other parts of Finland, not only Sápmi (Kärnä 2014a,b). This view is not shared by Metsähallitus and the Ministry of the Environment. However, indeed, it can be seen as an example of how facts and knowledge, meanings and definitions can be situated and partial, and objects of struggle.

Coming back to the challenges identified by the officials, it is important to note that the incorporation of different knowledge systems into land use planning should not be seen just as a technical challenge, because it leaves out the political dimensions of knowledge incorporation processes (Nadasdy 2003a). There are recent land and resource use cases in different parts of Sápmi such as the Tana River Agreement and the Arctic Ocean Railway plan that have left Sámi knowledge and points of view unacknowledged (see Holmberg 2018, Finnish Transport Agency 2018). Accordingly, the Sámi informants asserted that it is very case dependent whether their views have an impact on the decisions made. The ways in which TLK is included in decision making and land use planning may be defined by a variety of issues from economical, e.g., monetary value of a plan, to political, e.g., power relations, to personal, e.g. perceptions of truth, evidence, and validity of knowledge.

\section{Application of the Akwé: Kon Guidelines}

In a letter approving the Land Use and Management Plan of Hammastunturi Wilderness Area, the Ministry of the Environment (2016) stated that application of the Akwé: Kon procedure had brought important added values to the management planning process and interactions in the area. The Hammastunturi plan was an update of an earlier land use and management plan (Metsähallitus 1996). When the two plans were compared in a study, it was found that the cultural heritage and traditional livelihoods of the Sámi were taken into consideration more extensively in the newer plan and that the Sámi were referred to as an Indigenous people rather than a minority (Meriläinen 2015). The newer plan is also more pluralistic with regard to environmental values and, in particular, cultural values are given more emphasis than before (Meriläinen 2015). These findings accord with the answers of some our respondents, who felt that application of the Akwé: Kon protocol had led to more diverse views being represented in land use and management plans. There are also indications that application of the Akwé: Kon Guidelines has led to a better recognition of biocultural diversity, Indigenous rights, and the cultural value of Indigenous livelihoods in management planning (Sarkki et al. 2018). The Sámi parliament has noted, however, that the views and statements of Akwé: Kon groups are not always well enough taken into account in final plans (Olsén et al. 2017). Akwé: Kon groups are set up each time a planning process starts, and it has been pointed out that the resources allocated for different groups vary between planning processes (Olsén et al. 2017), which inevitably affects the participation of the Sámi. For example, there were eight members in the first Akwé: Kon group (Juntunen and Stolt 2013), while in later ones the usual number of members has been five (e.g., Metsähallitus $2017 a, b, c)$. The goals and responsibilities of the groups also vary depending on the case and area in question. However, the Akwé: Kon process should, in any case, include either coproduction or parallel ways of knowledge production, not just consultation of the group members through official hearings. As the Guidelines state, "indigenous and local communities should be invited to participate in and are to be accorded full respect at all stages of the assessment and development process, including planning and implementation" (Secretariat of the CBD 2004:10).

When viewed through the MEB approach, the Akwé: Kon process applied by Metsähallitus can be seen as a step toward parallel knowledge production and in part, knowledge coproduction. Prior to application of the Akwé: Kon Guidelines, the planning system of Metsähallitus was more of a knowledge integration process because the participants' views were heard in public hearings and stakeholder group meetings and registered by officials, and the Sámi Parliament gave its statements after the plans had been completed. When the Guidelines are applied in land use and management planning, Sámi representatives participate from the onset, and the impact assessment process is continuous (Juntunen and Stolt 2013). Therefore, application of the Guidelines is a necessary improvement in land use and management planning of wilderness areas and brings a whole new element into participatory planning. But is it genuine coproduction of knowledge? According to Tengö et al. (2014), "co-production of knowledge entails engaging in mutual processes of knowledge generation at all stages of knowledge 
generation, such as for example an assessment, including validation." Coproduction of knowledge is part of many cases of community-based management, participatory natural resource monitoring, and comanagement of natural resources (e.g., Danielsen et al. 2009, Armitage et al. 2011, Berkes 2012, Tengö et al. 2014). Berkes (1994) has described comanagement as a bridge between government-based systems (centralized authorities relying on scientific information and regulatory mechanisms) and local-level systems (decentralized entities relying on traditional knowledge and self-regulation). Moreover, Berkes (2009) considers comanagement as "a knowledge partnership" and a problem-solving process, which involves negotiation, deliberation, knowledge generation, and joint learning. Thus, knowledge coproduction requires comanagement and vice versa.

Plummer and Fitzgibbon (2004) have defined three outcomes of a comanagement process: (1) equity and efficiency in decision making, (2) legitimization of actions, and (3) greater capacity at the local level. According to a recent study by Sormunen (2017), the management planning of the Hammastunturi Wilderness Area partly fulfils these criteria set for a comanagement practice. It is stated in the report describing the first application of Akwé: Kon Guidelines that "[a]ccording to current legislation, the final authority in terms of validating, for instance, management and land use plans lies at ministry level, but wide-scale, effective engagement of stakeholders and citizens is, at its best, already approaching actual local power of decision" (Väisänen 2013:7). However, regarding equity in decision making as a criterion for comanagement, it is noteworthy that the authority lies at the ministry level. Regarding legitimization of actions, Sormunen (2017) noted that the Akwé: Kon process can enhance the credibility of the actions taken by Metsähallitus among local residents because planning is based on legislation and broadly engages stakeholders and citizens, and the Sámi have their own forum where they can express their views and concerns. It can also lead to greater capacity at the local level, i.e., giving more possibilities for locals to have real impact on decision making. However, greater capacity at the local level requires decentralization of power in decision making, which is not the case in the application of the Akwé: Kon Guidelines whereby decision-making power lies with Metsähallitus as state authority (Sormunen 2017). Kearney et al. (2007:82) pointed out that higher levels of community and citizen participation in collaborative resource governance processes with government should result in greater decision-making powers for the communities, by "moving them from an advisory capacity to inclusive governance in a participatory and citizen empowered democracy." At the same time, when government increases its collaboration with the local community, its share of decision-making powers should decrease through delegation of authority to the local level. Thus, comanagement is essentially about sharing of decision-making powers (Kearney et al. 2007).

At present, the Guidelines are applied chiefly by Metsähallitus in wilderness area and national park planning, leaving out other contexts such as, e.g., regional natural resource and municipallevel planning, EIA, and permits for test drilling, and thus, the impacts are local. Adoption of voluntary guidelines cannot solve long-standing issues such as the question of the Sámi rights to land and resources. Legal instruments, such as the Reindeer
Husbandry Act and ILO 169 Convention, are more central in this regard. However, comanagement, recognition of TLK, and land claims are often connected. In Canada, the agreements of land claims of Indigenous people have formalized the sharing of power and responsibility between the government and local resource users, and therefore, resource comanagement (Notzke 1995). Also, the recognition of Indigenous and traditional knowledge has been for quite long a required component of various EIAs as well as an important aspect of Indigenous land claims (Usher 2000, Berkes et al. 2001). In the context of Arctic Canada, comanagement has been defined as an institutional arrangement where governments and Indigenous parties "enter into formal agreements specifying their respective rights, powers and obligations with reference to the management and allocation of resources in a particular area" (Royal Commission on Aboriginal Peoples 1996). The Akwé: Kon process applied by Metsähallitus, which so far has created a separate, permanent forum for the Sámi to express their views and concerns and to take part in impact assessments from the onset, has all potential to develop into a true comanagement practice.

There is a long history of land use conflicts in Finnish Sápmi (e. g., Lawrence 2007, Heikkinen et al. 2010, Mustajoki et al. 2011). Use of the Akwé: Kon Guidelines in Sápmi is part of Finland's strategy for implementation of the CBD, in particular its Article $8(\mathrm{j})$, and their application may also work in preventing new landuse conflicts in the area. The Sámi parliament has suggested the Akwé: Kon Guidelines to be applied to construction projects carried out under the Land Use and Building Act (Ministry of Justice 1999) and for EIA (Olsén et al. 2017). Recently, there have been protests over plans for the Arctic Ocean Railway (Finnish Transport Agency 2018), which would cut through the Sámi lands and reindeer pastures. The Arctic Ocean Railway plan is strongly opposed by the Sámi population and they have stated that the plan does not take into account Sámi views and their rights to participate in decision making (Nilsen 2017, Saami Council 2018). Thus, there is definitely a need to broaden the application of the Akwé: Kon Guidelines in Finnish Sápmi. However, it remains to be seen whether the Guidelines can provide or add to protection for Sámi rights in a region with increasing land use pressure, industrial developments and challenges arising from climate change.

\section{CONCLUSIONS}

We examined the use of Akwé: Kon Guidelines, inclusion of TLK, and the related challenges and improvements in land use planning and wilderness area management in the municipality of Eanodat in Finnish Sápmi. The officials interviewed mentioned practical challenges such as the mismatch between the oral narrative nature of TLK and the planning systems currently in use, as well as the need to make TLK more spatially explicit, while the needs brought up by the Sámi informants were tied to the survival of their traditional livelihoods. The Sámi informants were unanimous regarding the need to amend the Reindeer Husbandry Act (Ministry of Agriculture and Forestry 1990) to secure traditional Sámi livelihoods and knowledge.

The application of the Akwé: Kon Guidelines is a welcome development: It has strengthened the opportunities of the Sámi to participate in management planning and, as such, constitutes a step toward a more equitable way of connecting different knowledge systems in land use planning. The application of the 
Akwé: Kon Guidelines can change the ways in which TLK is incorporated into planning. When viewed through the MEB approach (Tengö et al. 2014), the Akwé: Kon process applied by Metsähallitus can be seen as a step from knowledge integration toward parallel ways of knowledge production and knowledge coproduction. However, the power of such a voluntary procedure is limited in the current situation in which Sámi reindeer herders' rights are not settled in national legislation. It remains to be seen whether application of the Guidelines can provide adequate protection of Indigenous rights in Sápmi, where climate change brings great challenges, land use pressure is increasing, and new development plans arise.

Responses to this article can be read online at: http://www.ecologyandsociety.org/issues/responses. php/10735

\section{Acknowledgments:}

We are grateful to all of the informants who participated in this study. We would also like to thank Risto Viitanen for making the map and Richard Foley and Sari Kokkola for checking the language of the manuscript. This study was conducted as part of the project Building Shared Knowledge Capital to Support Natural Resource Governance (BuSK), funded by the EU Interreg Northern Periphery and Arctic Programme.

\section{LITERATURE CITED}

Agrawal, A. 2014. Indigenous and scientific knowledge: some critical comments. Anthropologi Indonesia 2014/3331. http://dx. doi.org/10.7454/ai.v0i55.3331

Äikäs, T. 2013. “Kelle se tieto kuuluu, ni sillä se on.” Osallistava GIS Pohjois-Suomen pyhien paikkojen sijaintietoon liittyvien näkemysten kartoituksessa. [Participatory GIS in surveying the views on the location of sacred sites in northern Finland. Title translated from the Finnish.] Thesis. University of Oulu, Finland. [online] URL: http://jultika.oulu.fi/files/nbnfioulu-201306011417. pdf

Alessa, L., A. Kliskey, and G. Brown. 2008. Social-ecological hotspots mapping: a spatial approach for identifying coupled social-ecological space. Landscape and Urban Planning 85:27-39. http://dx.doi.org/10.1016/j.landurbplan.2007.09.007

Arctic Council. 2015. Ottawa traditional knowledge principles. Arctic Council, Tromsø, Norway. [online] URL: http://www. saamicouncil.net/fileadmin/user_upload/Documents/Eara_dokumeanttat/ Ottawa TK Principles.pdf

Armitage, D., F. Berkes, A. Dale, E. Kocho-Schellenberg, and E. Patton. 2011. Co-management and the co-production of knowledge: learning to adapt in Canada's Arctic. Global Environmental Change 21:995-1004. http://dx.doi.org/10.1016/j. gloenvcha.2011.04.006

Aslaksen, I., K. J. Jonsen, A. M. Magga, and W. van Rooij. 2017. Indigenous peoples' perspectives. Pages 167-194 in Adaptation actions for a changing Arctic: perspectives from the Barents Area. Arctic Monitoring and Assessment Programme (AMAP), Oslo, Norway.
Barlindhaug, S. 2013. Cultural sites, traditional knowledge and participatory mapping. Long-term land use in a Sámi community in coastal Norway. Dissertation. University of Tromsø, Norway. [online] URL: https://munin.uit.no/bitstream/handle/10037/5405/ thesis.pdf? sequence $=2$

Berkes, F. 1994. Co-management: bridging the two solitudes. Northern Perspectives 22:18-20.

Berkes, F. 2009. Evolution of co-management: role of knowledge generation, bridging organizations and social learning. Journal of Environmental Management 90:1692-1702. http://dx.doi.org/10.1016/ j.jenvman.2008.12.001

Berkes, F. 2012. Sacred ecology. Third edition. Routledge, New York, New York, USA. http://dx.doi.org/10.4324/9780203123843

Berkes, F., M. Kislalioglu Berkes, and H. Fast. 2007. Collaborative integrated management in Canada's north: the role of local and traditional knowledge and community-based monitoring. Coastal Management 35:143-162. http://dx.doi.org/10.1080/08920750600970487

Berkes, F., J. Mathias, M. Kislalioqlu, and H. Fast. 2001. The Canadian Arctic and the Oceans Act: the development of participatory environmental research and management. Ocean and Coastal Management 44:451-469. http://dx.doi.org/10.1016/ S0964-5691(01)00060-6

Brown, G., and M. Kyttä. 2014. Key issues and research priorities for public participation GIS (PPGIS): a synthesis based on empirical research. Applied Geography 46:122-136. http://dx.doi. org/10.1016/j.apgeog.2013.11.004

Brown, G., and D. Weber. 2012. Measuring change in place values using public participation GIS (PPGIS). Applied Geography 34:316-324. http://dx.doi.org/10.1016/j.apgeog.2011.12.007

Callaway, D. G. 2004. Landscapes of tradition, landscapes of resistance. Pages 177-201 in I. R. Krupnik, R. Mason, and T. Horton, editors. Northern ethnographic landscapes: perspectives from circumpolar nations. Smithsonian Institution Arctic Studies Center and National Parks Service, Washington, D.C., USA.

Carstens, M. 2016. Sami land rights: the Anaya Report and the Nordic Sami Convention. Journal on Ethnopolitics and Minority Issues in Europe 15:75-116. [online] URL: http://www.ecmi.de/ fileadmin/downloads/publications/JEMIE/2016/Carstens.pdf

Casimirri, G. 2003. Problems with integrating traditional ecological knowledge into contemporary resource management. XII World Forestry Congress, Québec City, Québec, Canada. [online] URL: http://www.fao.org/docrep/ARTICLE/WFC/ XII/0887-A3.HTM

Christensen, J., and M. Granti. 2007. How political change paved the way for Indigenous knowledge: the Mackenzie Valley Resource Management Act. Arctic 60:115-123.

Cruikshank, J. 1998. The social life of stories: narrative and knowledge in the Yukon Territory. University of British Columbia Press, Vancouver, British Columbia, Canada.

Dale, A., and D. Armitage. 2011. Marine mammal comanagement in Canada's Arctic: knowledge co-production for learning and adaptive capacity. Marine Policy 35:440-449. http:// dx.doi.org/10.1016/j.marpol.2010.10.019 
Dallman, W. K., V. Peskov, O. A. Murashko, and E. Khmeleva. 2011. Reindeer herders in the Timan-Pechora oil province of northwest Russia: an assessment of interacting environmental, social, and legal challenges. Polar Geography 34:229-247. http:// dx.doi.org/10.1080/1088937X.2011.632826

Danielsen, F., N. D. Burgess, A. Balmford, P. F. Donald, M. Funder, J. P. G. Jones, P. Alviola, D. S. Balete, T. Blomley, J. Brashares, et al. 2009. Local participation in natural resource monitoring: a characterization of approaches. Conservation Biology 23:31-42. http://dx.doi.org/10.1111/j.1523-1739.2008.01063. $\underline{\mathrm{x}}$

Davidson-Hunt, I. J., and R. M. O'Flaherty. 2007. Researchers, Indigenous peoples, and place-based learning communities. Society and Natural Resources 20:291-305. http://dx.doi. org/10.1080/08941920601161312

Dyson, S., and B. Brown. 2006. Social theory and applied health research. Open University Press, McGraw-Hill Education, Maidenhead, UK.

Eira, I. M. G., C. Jaedicke, O. H. Magga, N. G. Maynard, D. Vikhamar-Schuler, and S. D. Mathiesen. 2013. Traditional Sámi snow terminology and physical snow classification - two ways of knowing. Cold Regions Science and Technology 85:117-130. http:// dx.doi.org/10.1016/j.coldregions.2012.09.004

Eybursson, E., and A. E. Thuestadt. 2015. Incorporating traditional knowledge in environmental impact assessment. How can it be done? Arctic Review on Law and Politics 6:132-150.

Finnish Transport Agency. 2018. Arctic Ocean railway report. Finnish Transport Agency, Helsinki, Finland.

Firestone, W. A. 1987. Meaning in method: the rhetoric of quantitative and qualitative research. Educational Researcher 16:16-21. http://dx.doi.org/10.3102/0013189X016007016

Folke, C., Å. Jansson, J. Rockström, P. Olsson, S. R. Carpenter, F. S. Chapin III, A.-S. Crépin, G. Daily, K. Danell, J. Ebbeson, T. Elmqvist, V. Galaz, F. Moberg, M. Nilsson, H. Österblom, E. Ostrom, Å. Persson, G. Peterson, S. Polansky, W. Steffen, B. Walker, and F. Westley. 2011. Reconnecting to the Biosphere. Ambio 40:719-738. http://dx.doi.org/10.1007/s13280-011-0184-y

Forbes, B. C., M. Bölter, L. Müller-Wille, J. Hukkinen, F. Müller, N. Gunslay, and Y. Konstantinov, editors. 2006. Reindeer management in northernmost Europe: linking practical and scientific knowledge in social-ecological systems. Ecological Studies 184, Springer, Berlin, Germany. http://dx.doi. org/10.1007/3-540-31392-3

Forbes, B. C., and F. Stammler. 2009. Arctic climate change discourse: the contrasting politics of research agendas in the West and Russia. Polar Research 28:28-42. http://dx.doi.org/10.1111/ j.1751-8369.2009.00100.x

Gearheard, S. F., L. Kielsen Holm, H. Huntington, J. M. Leavitt, A. R. Mahoney, M. Opie, T. Oshima, and J. Sanguya. 2013. The meaning of ice. People and sea ice in three Arctic communities. International Polar Institute Press, New Hampshire, USA.

Gondor, D. 2016. Inuit knowledge and environmental assessment in Nunavut, Canada. Sustainability Science 11:153-162. http://dx. doi.org/10.1007/s11625-015-0310-z
Gratani, M., J. R. A. Butler, F. Royee, P. Valentine, D. Burrows, W. I. Canendo, and A. S. Anderson. 2011. Is validation of indigenous ecological knowledge a disrespectful process? A case study of traditional fishing poisons and invasive fish management from the Wet Tropics, Australia. Ecology and Society 16(3):25. http://dx.doi.org/10.5751/ES-04249-160325

Heikkilä, L. 2006a. The comparison of Indigenous and scientific perceptions of reindeer management. Pages 73-93 in B. C. Forbes, M. Bölter, L. Müller-Wille, J. Hukkinen, F. Müller, N. Gunslay, and Y. Konstantinov, editors. 2006. Reindeer management in northernmost Europe: linking practical and scientific knowledge in social-ecologicalsystems. Ecological Studies 184, Springer, Berlin, Germany. http://dx.doi.org/10.1007/3-540-31392-3 5

Heikkilä, L. 2006b. Reindeer talk. Sámi reindeer herding andnature management. Dissertation. University of Lapland, Rovaniemi, Finland.

Heikkinen, H. I., S. Sarkki, M. Jokinen, and D. E. Fornander. 2010. Global area conservation ideals versus the local realities of reindeer herding in Northernmost Finland. International Journal of Business and Globalisation 4:110-130. http://dx.doi. org/10.1504/IJBG.2010.030665

Heikkonen, A. 2014. Ylimuonion käyttösuunitelma. [Ylimuonio management plan. Title translated from the Finnish.] Metsähallituksen metsätalouden julkaisuja 70. Metsähallitus, Vantaa, Finland.

Heinämäki, L., T. M. Herrmann, and A. Neumann. 2014. The protection of culturally and spiritually important landscapes of Arctic Indigenous Peoples under the Convention on Biological Diversity and first experiences from the application of the Akwé: Kon Guidelines in Finland. Yearbook of Polar Law Online 6:189-225. http://dx.doi.org/10.1163/1876-8814 008

Heinämäki, L., S. Valkonen, L. Olsén, C. Allard, S. Kircher, and A. Xanthaki. 2017. Saamelaisten oikeuksien toteutuminen: kansainvälinen oikeusvertaileva tutkimus. [Actualizing Sámi rights: international comparative research. Title translated from the Finnish.] Valtioneuvoston selvitys-ja tutkimustoiminnan julkaisusarja 4. Valtioneuvosto, Helsinki, Finland.

Henriksen, J. B. 2011. Árbediehtu: some legal reflections. Pages 77-97 in J. Porsanger and G. Guttorm, editors. Working with traditional knowledge: communities, institutions, information systems, law and ethics. Diedut 1/11. Sami allaskuvla, Guovdageaidnu, Norway.

Holmberg, A. 2018. Bivdit Luosa - to ask for salmon. Saami traditional knowledge on salmon and the River Deatnu: in research and decision-making. Thesis. The Arctic University of Norway, Tromsø, Norway.

Horstkotte, T., T. A. Utsi, Å. Larsson-Blind, P. Burgess, B. Johansen, J. Käyhkö, L. Oksanen, and B. C. Forbes. 2017. Human-animal agency in reindeer management: Sámi herders' perspectives on vegetation dynamics under climate change. Ecosphere 8(9):e01931. http://dx.doi.org/10.1002/ecs2.1931

Houde, N. 2007. The six faces of traditional ecological knowledge: challenges and opportunities for Canadian co-management arrangements. Ecology and Society 12(2):34. http://dx.doi. org/10.5751/ES-02270-120234 
Huntington, H. P. 2000. Using traditional ecological knowledge in science: methods and applications. Ecological Applications 10:1270-1274. http://dx.doi.org/10.1890/1051-0761(2000)010[1270: UTEKIS]2.0.CO;2

Jaakkola, J. J. K., S. Juntunen, and K. Näkkäläjärvi. 2018. The holistic effects of climate change on the culture, well-being, and health of the Saami, the only Indigenous People in the European Union. Current Environmental Health Reports 5(4):401-417. http://dx.doi.org/10.1007/s40572-018-0211-2

Johnsen, K. I., T. A. Benjaminsen, and I. M. G. Eira. 2015. Seeing like the state or like pastoralists? Conflicting narratives on the governance of Sámi reindeer husbandry in Finnmark, Norway. Norwegian Journal of Geography 69:230-241. http://dx.doi. org/10.1080/00291951.2015.1033747

Jokinen, M. 2014. Heated and frozen forest conflicts: cultural sustainability and forest management in Arctic Finland. Pages 381-199 in P. Katila, G. Galloway, W. de Jong, P. Pacheco, and G. Mery, editors. Forests under pressure - local responses to global issues. International Union of Forest Research Organizations, Vienna, Austria.

Jokinen, M., S. Sarkki, and H. I. Heikkinen. 2016. The well-being effects of localized multi-level environmental governance: case of Kilpisjärvi. Nordia Geographical Publications Yearbook 2016: Geographies of Well-Being in the North 45:19-36.

Juntunen, S., and E. Stolt. 2013. Application of Akwé: Kon Guidelines in the management and land use plan for the Hammastunturi Wilderness Area. Metsähallitus, Natural Heritage Services, Finland. [online] URL: https://www.cbd.int/ doc/world/fi/fi-nr-oth-en.pdf

Kärnä, M. 2014a. Kolme syytä vastustaa esitettyä metsähallituslakia. [Three reasons to oppose the Act on Metsähallitus. Title translated from the Finnish.] Uusi Suomi, Finland. [online] URL: http://mikkokarna.puheenvuoro.uusisuomi.fi/167651-kolme-syytavastustaa-esitettya-metsahallituslakia

Kärnä, M. 2014b. Seitsemän askelta ILO-169 yleissopimuksen ratifioimiseksi. [Seven steps to ratification of ILO 169. Title translated from the Finnish.] Uusi Suomi, Finland. [online] URL: http://mikkokarna.puheenvuoro.uusisuomi.fi/168987-7-askelta-ilo-169yleissopimuksen-ratifioimiseksi

Kearney, J., F. Berkes, A. Charles, E. Pinkerton, and M. Wiber. 2007. The role of participatory governance and community-based management in integrated coastal and ocean management in Canada. Coastal Management 35:79-104. http://dx.doi. org/10.1080/10.1080/08920750600970511

Kiernan, M. J. 1983. Ideology, politics, and planning: reflections on the theory and practice of urban planning. Environment and Planning B: Urban Analytics and City Science 10:71-87. http://dx. doi.org/10.1068/b100071

Kitti, H., N. Gunslay, and B. C. Forbes. 2006. Defining the quality of reindeer pastures: the perspectives of Sámi reindeer herders. Pages 141-165 in B. C. Forbes, M. Bölter, L. Müller-Wille, J. Hukkinen, F. Müller, N. Gunslay, and Y. Konstantinov, editors. Reindeer management in northernmost Europe: linking practical and scientific knowledge in social-ecological systems. Ecological Studies 184, Springer, Berlin, Germany. http://dx.doi. org/10.1007/3-540-31392-3 8
Lawrence, R. 2007. Corporate social responsibility, supply chains and Saami claims: tracing the political in the Finnish Forestry Industry. Geographical Research 45(2):167-176. http://dx.doi. org/10.1111/j.1745-5871.2007.00448.x

Lefler, T. E. 2010. Successful community-based monitoring in Canada: three case studies. Thesis. University of Guelph, Guelph, Ontario, Canada.

Lehtola, V.-P. 2004. The Sami people: traditions in transition. University of Alaska Press, Fairbanks, Alaska, USA.

Ludwig, D. 2016. Overlapping ontologies and Indigenous knowledge from integration to ontological self-determination. Studies in History and Philosophy of Science Part A 59:36-45 http://dx.doi.org/10.1016/j.shpsa.2016.06.002

Magga, H. 2003. Poronhoidon menetykset ja sopeutuminen suuriin ympäristömuutoksiin Lapin paliskunnassa 1950-luvulta lähtien. [Loss and adaptations in reindeer herding in the Lappi reindeer herding cooperative due to considerable environmental changes since the 1950s. Title translated from the Finnish.] Technology, Society and Environment 3:11-78.

Mazzullo, N. 2010. More than meat on the hoof? Social significance of reindeer among Finnish Saami in a rationalized pastoralist economy. Pages 101-119 in F. Stammler and $\mathrm{H}$. Takakura, editors. Good to eat, good to live with: nomads and the animals in northern Eurasia and Africa. Northeast Asian Study Series 11, Center for Northeast Asia Studies, Tohoku University, Sendai, Japan.

Mazzullo, N. 2013. The Nellim Forest conflict in Finnish Lapland: between state forest mapping and local forest living. Pages 91-112 in J. Miggelbrink, O. J. Habeck, N. Mazzullo, and P. Koch, editors. Nomadic and Indigenous spaces: productions and cognitions. Routledge, London, UK.

Meriläinen, M. 2015. Akwé: Kon -ohjeiden vaikutus saamelaisnäkökulman huomioimiseen Hammastunturin erämaaalueen hoitoja käyttösuunnitelmassa. [The effect of the Akwé: Kon Guidelines on the consideration of the Sami perspective in the management plan of Hammastunturi Wilderness area. Title translated from the Finnish.] Thesis. University of Helsinki, Helsinki, Finland. [online] URL: https://helda.helsinki.fi/ bitstream/handle/10138/158595/ethesispdf.pdf?sequence=2

Metsähallitus. 1996. Hammastunturin erämaan hoito- ja käyttösuunnitelma. [Land use and management plan of Hammastunturi Wilderness Area. Title translated from the Finnish.] Metsähallituksen luonnonsuojelujulkaisuja B 32. Metsähallitus, Vantaa, Finland.

Metsähallitus. 2016. Hammastunturin erämaa-alueen hoito- ja käyttösuunnitelma. [Land use and management plan of the Hammastunturi Wilderness Area. Title translated from the Finnish.] Metsähallituksen luonnonsuojelujulkaisuja C 124. Metsähallitus, Vantaa, Finland.

Metsähallitus. 2017a. Käsivarren erämaa-alueen hoito- ja käyttösuunnitelma. [Land use and management plan of Käsivarsi Wilderness Area. Title translated from the Finnish.] Metsähallitus, Vantaa, Finland. [online] URL: http://www.metsa. fi/documents/10739/1110148/kasivarren_hks_lausunnolle.pdf/d9b8616ee462-41a2-b8b2-55b27bb9c67f 
Metsähallitus. 2017b. Saanan alueen hoito- ja käyttösuunnitelma. [Land use and management plan of Saana Area. Title translated from the Finnish.] Draft for comments. Metsähallitus, Vantaa, Finland. [online] URL: http://www.metsa.fi/documents/10739/1110148/ saana hks yhteenveto.pdf/9db5ffa2-5885-4fc4-8d2f-2da0424fa94e

Metsähallitus. 2017c. Kevon luonnonpuiston ja Natura 2000 alueen hoito- ja käyttösuunnitelma. [Land use and management plan of the Kevo Nature Protection and Natura 2000 Area. Title translated from the Finnish.] Metsähallituksen luonnonsuojelujulkaisuja C 149. Metsähallitus, Vantaa, Finland.

Metsähallitus. 2018. Puljun erämaan Natura-alueen hoito- ja käyttösuunnitelma. [Land use and management plan of the Pulju Wilderness Natura Area. Title translated from the Finnish.] Metsähallituksen luonnonsuojelujulkaisuja C 162, Vantaa, Finland.

Ministry of Agriculture and Forestry. 1990. Reindeer Husbandry Act (848/1990). Ministry of Agriculture and Forestry, Government of Finland, Helsinki, Finland. [online] URL: http:// www.finlex.fi/fi/laki/kaannokset/1990/en19900848.pdf

Ministry of Justice. 1995. Act on the Sámi Parliament (974/1995). Ministry of Justice, Government of Finland, Helsinki, Finland. [online] URL: http://www.finlex.fi/fi/laki/kaannokset/1995/en19950974. pdf

Ministry of Justice. 1999. Land Use and Building Act (132/1999). Ministry of Justice, Government of Finland, Helsinki, Finland. [online] URL: http://www.finlex.fi/fi/laki/kaannokset/1999/en19990132. pdf

Ministry of Justice. 2011. Mining Act (621/2011). Ministry of Justice, Government of Finland, Helsinki, Finland. [online] URL: http://www.finlex.fi/fi/laki/kaannokset/2011/en20110621. pdf

Ministry of Justice. 2016. Act on Metsähallitus (234/2016). Ministry of Justice, Government of Finland, Helsinki, Finland. [online] URL: http://www.finlex.fi/fi/laki/alkup/2016/20160234

Müller-Wille, L., J. Hukkinen, F. Müller, M. Bölter, and B. C. Forbes. 2006. Synthesis: environmental and socio-political conditions for modern reindeer management in Europe's north. Pages 365-379 in B. C. Forbes, M. Bölter, L. Müller-Wille, J. Hukkinen, F. Müller, N. Gunslay, and Y. Konstantinov, editors. Reindeer management in northernmost Europe: linking practical and scientific knowledge in social-ecological systems. Ecological Studies 184, Springer, Berlin, Germany. http://dx.doi. org/10.1007/3-540-31392-3 18

Murphy, B. L. 2011. From interdisciplinary to interepistemological approaches: confronting the challenges of integrated climate change research. Canadian Geographer / Le Géographe Canadien 55:490-509. http://dx.doi.org/10.1111/ j.1541-0064.2011.00388.x

Mustajoki, J., H. Saarikoski, M. Marttunen, A. Ahtikoski, V. Hallikainen, T. Helle, M. Hyppönen, M. Jokinen, A. Naskali, S. Tuulentie, et al. 2011. Use of decision analysis interviews to support the sustainable use of the forests in Finnish Upper Lapland. Journal of Environmental Management 92(6):1550-1563. http://dx.doi.org/10.1016/j.jenvman.2011.01.007
Mustonen, K., T. Mustonen, A. Aikio, and P. Aikio. 2010. Drowning reindeer, drowning homes - Indigenous Sámi and hydroelectricity development in Sompio, Finland. Snow Change Co-operation, Vaasa, Finland.

Nadasdy, P. 1999. The politics of TEK: power and the 'integration' of knowledge. Arctic Anthropology 36:1-18.

Nadasdy, P. 2003a. Hunters and bureaucrats: power, knowledge, and Aboriginal-state relations in the southwest Yukon. University of British Columbia Press, Vancouver, British Columbia, Canada.

Nadasdy, P. 2003b. Re-evaluating the co-management success story. Arctic 56:367-380. http://dx.doi.org/10.14430/arctic634

Nadasdy, P. 2005. The anti-politics of TEK: the institutionalization of co-management discourse and practice. Anthropologica 47:215-32.

Nakashima, D., and M. Roué. 2002. Indigenous knowledge, peoples and sustainable practice. Pages 314-324 in T. Munn, editors. Encyclopedia of global environmental change. Wiley, Chichester, UK.

Näkkäläjärvi, K., and J. J. K. Jaakkola. 2017. Saamelaiset ja muutos. Pages 44-63 in M. Tennberg, A. Emelyanova, H. Eriksen, and J. Haapala, editors. Barentsin alue muuttuu - Miten Suomi sopeutuu. [The Barents area is changing - how will Finland adapt? Title translated from the Finnish.] Valtioneuvoston selvitys-ja tutkimustoiminnan julkaisusarja 4. Valtioneuvosto, Helsinki, Finland.

Nilsen, T. 2017. Sámi concerned about Arctic railway plans. The Barents Observer, 19 June. [online] URL: https://thebarentsobserver. com/en/life-and-public/2017/06/sami-concerned-about-arctic-railwayplans

Norberg, E., and B. Fossum. 2011. Traditional knowledge and cultural landscape. Pages 193-223 in J. Porsanger and G. Guttorm, editors. Working with traditional knowledge: communities, institutions, information systems, law and ethics. Diedut 1/11. Sami allaskuvla, Guovdageaidnu, Norway.

Notzke, C. 1995. A new perspective in aboriginal natural resource management: co-management. Geoforum 26:187-209. http://dx. doi.org/10.1016/0016-7185(95)00019-H

Nykänen, T., and L. Valkeapää, editors. 2016. Kilpisjärven poliittinen luonto - matkoja Käsivarren kulttuurimaisemassa. [The political nature of Kilpisjärvi. Title translated from the Finnish.] Suomalaisen Kirjallisuuden Seura, Helsinki, Finland.

O'Flaherty, R. M., I. J. Davidson-Hunt, and M. Manseau. 2008. Indigenous knowledge and values in planning for sustainable forestry: Pikangikum First Nation and the Whitefeather Forest Initiative. Ecology and Society 13(1):6. http://dx.doi.org/10.5751/ ES-02284-130106

Olsén, S., A. Harkoma, L. Heinämäki, and H. Heiskanen. 2017. Saamelaisten perinnetiedon huomioiminen ympäristöpäätöksenteossa. [Recognition of Sami traditional knowledge in decision making. Title translated from the Finnish and Sami.] Juridica Laponica 41. Arktinen keskus, Lapin yliopisto, Rovaniemi, Finland. 
Peters, E. J. 2003. Views of traditional ecological knowledge in co-management bodies in Nunavik, Québec. Polar Record 39:49-60. http://dx.doi.org/10.1017/S0032247402002759

Plummer, R., and J. Fitzgibbon. 2004. Co-management of natural resources: a proposed framework. Environmental Management 33:876-885. http://dx.doi.org/10.1007/s00267-003-3038-y

Raitio, K. 2008. "You can't please everyone" - conflict management practices, frames and institutions in Finnish state forests. Dissertation. University of Joensuu, Joensuu, Finland.

Rambaldi, G., R. Chambers, M. Mc Call, and J. Fox. 2006. Practical ethics for PGIS practitioners, facilitators, technology intermediaries and researchers. Participatory Learning and Action 54:106-113.

Raymond, C. M., I. Fazey, M. S. Reed, L. C. Stringer, G. M. Robinson, and A. C. Evely. 2010. Integrating local and scientific knowledge for environmental management. Journal of Environmental Management 91:1766-1777. http://dx.doi.org/10.1016/ j.jenvman.2010.03.023

Reindeer Herders' Association. 2018. Statistics of reindeer husbandry for 2015-2016. Poromies 2:32-33.

Riseth, J. A, and A. Vatn. 2009. Modernization and pasture degradation: a comparative study of two Sámi reindeer pasture regions in Norway. Land Economics 85:87-106. http://dx.doi. org/10.3368/le.85.1.87

Riseth, J. A.., H. Tømmervik, E. Helander-Renvall, N. Labba, C. Johansson, E. Malnes, J. W. Bjerke, C. Jonsson, V. Pohjola, L. E. Sarri, A. Schanche, and T. Callaghan. 2011. Sámi traditional ecological knowledge as a guide to science: snow, ice and reindeer pasture facing climate change. Polar Record 47:202-217. http:// dx.doi.org/10.1017/S0032247410000434

Roturier, S. 2011. Sami herders' classification system of reindeer winter pastures - a contribution to adapt forest management to reindeer herding in northern Sweden. Rangifer 31:61-69. http:// dx.doi.org/10.7557/2.31.1.2020

Royal Commission on Aboriginal Peoples. 1996. Report of the Royal Commission on Aboriginal Peoples Vol 2, Part 2. Supply and Services Canada, Ottawa, Ontario, Canada.

Saami Council. 2018. Statement on the Arctic Railway. Saami Council, Karasjok, Norway. [online] URL: http://www. saamicouncil.net/en/article/statement-on-the-arctic-railway/

Saarikoski, H., and K. Raitio. 2013. Science and politics in oldgrowth forest conflict in Upper Lapland. Nature and Culture 8:53-73. http://dx.doi.org/10.3167/nc.2013.080104

Sandström, P. 2015. A toolbox for co-production of knowledge and improved land use dialogues - the perspective of reindeer husbandry. Dissertation. Swedish University of Agricultural Sciences, Umeå, Sweden.

Sandström, P., C. Sandström, J. Svensson, L. Jougda, and K. Baer. 2012. Participatory GIS to mitigate conflicts between reindeer husbandry and forestry in Vilhelmina Model Forest, Sweden. Forestry Chronicle 88:254-260. http://dx.doi.org/10.5558/tfc2012-051

Sarkki, S., H. I. Heikkinen, V.-P. Herva, and J. Saarinen. 2018. Myths on local use of natural resources and social equity of land use governance: reindeer herding in Finland. Land Use Policy 77:322-331. http://dx.doi.org/10.1016/j.landusepol.2018.05.055

Secretariat of the Convention on Biological Diversity. 2004. Akwé: Kon voluntary guidelines for the conduct of cultural, environmental and social impact assessments regarding developments proposed to take place on, or which are likely to impact on, sacred sites and on lands and waters traditionally occupied or used by Indigenous and local communities. Secretariat of the Convention on Biological Diversity, Montréal, Québec, Canada. [online] URL: https://www.cbd.int/doc/publications/akwe-brochureen.pdf

Secretariat of the Convention on Biological Diversity. 2011. Tkarihwaié:ri code of ethical conduct to ensure respect for the cultural and intellectual heritage of Indigenous and local communities relevant to the conservation and sustainable use of biological diversity. Secretariat of the Convention on Biological Diversity, Montréal, Québec, Canada. [online] URL: https:// www.cbd.int/doc/publications/ethicalconduct-brochure-en.pdf

Sillanpää, L. 1994. Political and administrative responses to Sami self-determination. Dissertation. University of Helsinki, Helsinki, Finland.

Sormunen, J. 2017. Yhteishallintaa Hammastunturilla? Akwé: Kon -ohjeiden vaikutus Hammastunturin erämaa-alueen hallintaan. [Co-management in Hammastunturi? Impacts of Akwé: Kon Guidelines in management of Hammastunturi Wilderness Area. Title translated from the Finnish.] Thesis, University of Turku, Turku, Finland.

Tengö, M., R. Hill, P. Malmer, R. C. M. Raymond, M. Spierenburg, F. Danielsen, T. Elmqvist, and C. Folke. 2017. Weaving knowledge systems in IPBES, CBD and beyond - lessons learned for sustainability. Current Opinion in Environmental Sustainability 26:17-25. http://dx.doi.org/10.1016/j.cosust.2016.12.005

Tengö, M., P. Malmer, P. Borraz, C. Cariño, J. Cariño, T. Gonzales, J. Ishizawa, M. Kvarnström, O. Masardule, A. Morales, et al. 2012. Dialogue workshop on Knowledge for the 21st Century: Indigenous knowledge, traditional knowledge, science and connecting diverse knowledge systems. Usdub, Guna Yala, Panama, 10-13 April. Workshop Report. Stockholm Resilience Centre, Sweden. [online] URL: https://swed.bio/wp-content/ uploads/2015/12/Knowledge-for-the-21st-Century.pdf

Tengö, M., M. Malmer, E. Brondizio, T. Elmqvist, and M. Spierenburg. 2014. Connecting diverse knowledge systems for enhanced ecosystem governance: the multiple evidence base approach. Ambio 43:579-591. http://dx.doi.org/10.1007/ s13280-014-0501-3

Tunón, H., M. Kvarnström, and P. Malmer. 2015. Report from the project: Indigenous and local knowledge in a scoping study for a Nordic IPBES Assessment. Swedish Biodiversity Centre, Uppsala, Sweden.

Tuomi, J., and A. Sarajärvi. 2009. Laadullinen tutkimus ja sisällönanalyysi. [Qualitative research and content analysis. Title translated from the Finnish.] Gummerus, Jyväskylä, Finland.

Turi, E. I., and E. C. H. Keskitalo. 2014. Governing reindeer husbandry in western Finnmark: barriers for incorporating traditional knowledge in local-level policy implementation. Polar Geography 37:234-251. http://dx.doi.org/10.1080/1088937X.2014.953620 
Turner, N. J., M. Boelscher Ignace, and R. Ignace. 2000. Traditional ecological knowledge and wisdom of aboriginal peoples in British Columbia. Ecological Applications 10:1275-1287. http://dx.doi.org/10.1890/1051-0761(2000)010[1275: TEKAWO]2.0.CO;2

Tuulentie, S. 2017. Destination development in the middle of the Sápmi: whose voice is heard and how? Pages 122-137 in A. Viken and D. K. Müller, editors. Tourism and indigeneity in the Arctic. Channel View Publications, Bristol, UK.

United Nations (UN). 1992. Convention on Biological Diversity. United Nations, Rio de Janeiro, Brazil. [online] URL: https:// www.cbd.int/convention/text/default.shtml

United Nations Environment Programme (UNEP). 2013. Indicators relevant for traditional knowledge and customary sustainable use. UNEP/CBD/WG8J/8/9. Convention of Biological Diversity, Montréal, Québec, Canada. [online] URL: https://www.cbd.int/doc/meetings/tk/8jws-2014-03/

information/8jws-2014-03-wg8j-08-09-en.pdf

University of Lapland. 2009. Good scientific practice. Guidelines on research ethics at the University of Lapland. University of Lapland, Rovaniemi, Finland. [online] URL: http://arcticcentre. ulapland.fi/docs/Guidelines_on_Research_Ethics.pdf

Usher, P. J. 2000. Traditional ecological knowledge in environmental assessment and management. Arctic 3:183-193. http://dx.doi.org/10.14430/arctic849

Väisänen, R. 2013. Foreword. Pages 7-8 in S. Juntunen and E. Stolt, editors. Application of Akwé: Kon Guidelines in the management and land use plan for the Hammastunturi Wilderness Area. Metsähallitus, Natural Heritage Services, Finland. [online] URL: https://www.cbd.int/doc/world/fi/fi-nr-oth-en.pdf 


\section{Appendix 1. Definitions}

\section{Traditional knowledge}

"Refers to the knowledge, innovations and practices of indigenous and local communities around the world. Developed from experience gained over the centuries and adapted to the local culture and environment, traditional knowledge is transmitted orally from generation to generation. It tends to be collectively owned and takes the form of stories, songs, folklore, proverbs, cultural values, beliefs, rituals, community laws, local language, and agricultural practices, including the development of plant species and animal breeds.” (CBD 1992)

\section{Local knowledge}

"The knowledge that people in a given community have developed over time and continue to develop. It is based on experience, often tested over centuries of use, adapted to the local culture and environment, embedded in community practices, institutions, relationships and rituals, held by individuals or communities, dynamic and changing." (FAO 2004)

\section{Indigenous knowledge}

"A systematic way of thinking applied to phenomena across biological, physical, cultural and spiritual systems. It includes insights based on evidence acquired through direct and long-term experiences and extensive and multigenerational observations, lessons, and skills. It has developed over millennia and is still developing in a living process, including knowledge acquired today and in the future, and it is passed on from generation to generation. It goes beyond observations, ecological knowledge, and research, offering a unique 'way of knowing'." (Inuit Utqiagivik Declaration 2018)

\section{Practitioners' knowledge}

Refers to ways of knowing that people enact in their diverse activities on the land. "By spending time on the land, the relationship between humans and animals is enacted, and, in this context, skills develop, and knowledge evolves through practice" (Ingold 2000). This knowledge has been gained 
over decades, often since childhood, and is reflected in local practices (Ingold and Kurttila 2000, Forbes et al. 2006).

\section{References:}

Convention on Biological Diversity (CBD) 1992. https://www.cbd.int/

FAO 2004. What is local knowledge? [online] URL:

http://www.fao.org/tempref/docrep/fao/007/y5610e/y5610e00.pdf

Forbes, B.C., M. Bölter, L. Müller-Wille, J. Hukkinen, F. Müller, F., N. Gunslay, and Y.

Konstantinov (eds.) 2006. Reindeer management in northernmost Europe: linking practical and scientific knowledge in social-ecological systems. Ecological Studies 184, Springer, Berlin, Germany, 397 pp.

Ingold T. 2000. The perception of the environment: essays in livelihood, dwelling and skill.

London: Routledge, 465 pp.

Ingold T., and T. Kurttila 2000. Perceiving the environment in Finnish Lapland. Body and Society 6:183-196.

Inuit Utqiagivik Declaration 2018. https://www.arctictoday.com/wp-content/uploads/2018/07/2018Utigavik-Declaration.pdf 


\section{Appendix 2}

\section{Interview questions}

What kind of knowledge is collected to support land use planning in your area?

What kind of knowledge is the most relevant in land use planning?

What kind of knowledge has the greatest impact in decision making?

Is there knowledge that is not taken into account at all?

Are views of local people and their knowledge taken into account in land use planning? If not, how this could be improved?

How well locals are heard in land-use planning today, in comparison to earlier years?

Has the role of TLK in land-use planning changed (during your career/time when participating in land use planning processes and negotiations)?

What are the impacts of Convention on Biodiversity, Akwé: Kon guidelines and other international conventions in incorporating TLK into land use planning?

What kind of benefits and challenges you see in integration of TLK in land use planning? 